\title{
La experiencia de un mercado paralelo en El Salvador
}

\author{
Nelly Carolina de Franco
}

\section{Introducción}

Desde 1978, El Salvador ha sufrido una severa crisis política y económica.

El sector externo en particular se ha visto fuertemente afectado. Bajo las circunstancias de fuga de capital y una alarmante disminución de las resenvas internacionales, las autoridades monetarias decidieron implementar un sistema de tipo de cambio dual cuando crean el mercado paralelo en agosto de 1982.

El tipo de cambio en el mercado oficial permaneció fijo a 42.50 por dólar. En el mercado paralelo el tipo de cambio fue depreciado continuamente por los bancos comerciales pero siempre permaneció sobrevaluado.

En principio, se consideró que sólo aquellas transacciones consideradas como esenciales se efectuarlan en el mercado oficial. Entre estas transacciones tenemos: medicinas, materia prima, fuentes de energia, exportaciones tradicionales y pagos específicos de invisibles.

Al comenzar, el mercado paralelo solo abaros un pequeno porcentaje de las transacciones, pero gradualmente se fueron transfiriendo operaciones del mercado oficial al mercado paralelo. Esta situación terminó a principios de 1986, cuando la devaluación "oficial" tuvo lugar y el tipo de cambio se unificó de nuevo a $\$ 5.00$ por dólar.

- Este artículo se basa en la tesis de Maestria "The Experience of a Dual Exchange Market in El Salvador" presentada on Rice University en junio 1987. 
Durante los ańos 1982-1985 en que el mercado paralelo estuvo funcionando, la intervención en el mercado de divisas de parte de las autoridades monetarias continuó. Ciertas restricciones se aplicaron a los flujos de fondos, mientras que otras medidas liberaron algunos controles cambiarios.

El objetivo de este trabajo es examinar los efectos del mercado paralelo y el mercado negro sobre la demanda de importaciones, oferta de exportaciones y los ingresos fiscales derivados de este sistema de cambio dual. También se analizarán los efectos inflacionarios de las variaciones del tipo de cambio en el mercado paralelo y en el mercado negro. Se estima que este efecto del tipo de cambio se realiza a través de cambios en las expectativas inflacionarias.

En la primera parte del trabjao se presenta alguna evidencia sobre el carácter eminentemente dependiente de la economía salvadorena. Luego se presenta la evolución de las importaciones y exportaciones durante 1978-1986.

En la tercera parte se muestra la evolución de los principales indicadores económicos, la política fiscal, la política monetaria y el proceso inflacionario en el pais. La cuarta y quinta parte corresponden a los aspectos institucionales del control cambiario en el pais, medidas de control implementadas, sistema cambiario y transacciones comprendidas en el mercado paralelo. Luego se presenta el marco teórico para comprender las condiciones de comercio en economias pequenas; dentro de este acápite se presenta un modelo de intercambio comercial que presenta los efectos de tipos de cambio sobrevaluados sobre la asignación de recursos y sobre el consumo. La sexta parte provee el estudio empirico del papel desempenado por el mercado paralelo. Dentro de este estudio se encuentra un modelo econométrico y se presentan sus resultados. Por último terminamos el trabajo con algunas conclusiones.

\section{VInculación de la economía salvadorena con el sector externo}

Es un hecho conocido de todos la fuerte vinculación que presenta la economia salvadorena con el sector externo. Numerosos estudios y trabajos han tratado y demostrado esta realidad por to que aqui nos limitaremos únicamente a exponer algunos de los rasgos más sobresalientes de esta dependencia externa.

En 1979 las exportaciones de bienes representaban el $32.82 \%$ del producto nacional bruto, sin embargo, esta proporción ha venido disminuyendo presentando para 1985 un nivel del 19.57\%.

En cuanto a las importaciones de bienes, estas representaban en 
1978 un 33.39\%. Pero al igual que las exportaciones, a partir de ese ano la proporción sigue una tendencia decreciente hasta alcanzar un $24.23 \%$ en 1986.

Así, la relación exportaciones más importaciones de bienes con respecto al producto nacional bruto es de $43.80 \%$ en 1986, mucho menor que el $62.96 \%$ que representaban en 1979.

Esta disminución en cuanto a la participación de las importaciones y exportaciones en el producto nacional bruto, lejos de indicar una disminución en la dependencia externa del país, es indicadora de graves problemas económicos y políticos que afectan al país, algunos de los cuales mencionaremos más adelante.

Otro indicador igualmente importante de la dependencia externa son los impuestos provenientes del sector externo y que constituyen un fuerte ingreso para el gobierno. En 1979, los ingresos por este concepto alcanzaban el $49.14 \%$ del total de ingresos tributarios en 1983 representaban el $25.79 \%$ y en 1986 el $43.24 \%$.

Otro hecho igualmente importante sobre la vinculación al exterior lo constituye la incidencia tan alta que tienen las exportaciones sobre la inversión privada, el consumo privado, la oferta monetaria y otras variables macroeconómicas, incidencia que ha sido cuantificada en varios estudios realizados.

Con respecto al papel crucial que tienen las importaciones en el pais, podemos decir que la actividad industrial del pais tiene su fuerza motora en las importaciones. Los bienes importados intermedios constituyen más de la mitad del total de importaciones $59.67 \%$ en 1983 y $48.49 \%$ en 1986. Especialmente la producción manufacturera tiene un alto componente importado, haciendo el desarrollo industrial del pais en extremo suceptible de nuestra capacidad para importar.

Por último podemos mencionar que más del $60 \%$ del total de exportaciones del pais se concentra en un reducido número de bienes tradicionales de exportación cuyos principales compradores se reducen a unos cuantos paises: Estados Unidos, Alemania, Japón y los paises centroamericanos.

Es por tanto natural ante estos hechos esperar que la economía del pais sea bastante sensible a cambios en los precios del mercado mundial.

En resumen, la economia de El Salvador tipifica las economias abiertas de pequehos paises:

- Hay una gran concentración de las exportaciones en unos pocos artículos. 
- La producción de exportaciones más importaciones en relación al producto nacional bruto es alto.

- La mayoria de bienes importados lo constituyen las materias primas y los bienes intermedios que son muy costosos de producir intemamente en términos tanto monetarios como de tecnologia y personal calificado.

- Los ingresos de exportación provienen de un reducido número de palses y 10 mismo sucede con las importaciones.

- Sus ventas de exportación representan una proporción muy baja de las ventas totales mundiales por lo que es un tomador de precios de sus importaciones y de sus exportaciones.

II. Evoluclón de las exportaclones y de las importaclones 19781986

Aunque la economia salvadorena sigue siendo altamente dependiente del exterior, a partir de 1979 la participación de las importaciones y de las exportaciones ha venido descendiendo, como ya se mencionó antes, debido tanto a situaciones externas como a problemas domésticos.

El descenso de las exportaciones se ha debido principalmente a la recesión económica a nivel mundial y al descenso de la demanda por nuestros pricipales productos de exportación; a la situación de guerra e incertidumbre que vive el pais; a la existencia de un tipo de cambio sobrevaluado, especialmente en los afios 1980-1986, y a la falta de financiamiento.

Asl tambien, la crisis económica a nivel mundial junto con problemas financieros y de comercialización relacionados con el nuevo acuerdo internacional del caté condujeron a precios más bajos a nivel mundial para nuestro principal producto de exportación.

Por otro lado, las acciones de violencia y sabotaje fueron un factor decisivo en la reducción de la producción de nuestros principales productos de agroexportación sobre todo del algodón al encontrarse localizadas las tierras tradicionalmente usadas para este cultivo en las zonas conflictivas del territorio nacional. Igualmente, la guerra desincentivó grandemente la inversión y provocó una masiva fuga de capitales. Para terminar de agravar la situación, los cafetaleros se vieron afectados por la roya y por un virus aparecido por primera vez en 1980. Junto a esto, hubo un descenso en la demanda de nuestros productos consecuencia de la aparición en el mercado mundial de sustitutos artificiales del azúcar y el całé a más bajos precios. 
De igual forma, un tipo de cambio sobrevaluado significó para los exportadores recibir las ganancias de exportación convertidas a colones a una tasa de cambio mucho más baja que la considerada como "real" y este motivo fue mencionado muchas veces por los exportadores como la razón de la brusca caida en las exportaciones.

En cuanto a las importaciones, estas constituian $₫ 2,404$ millones en 1980 cifra ligeramente inferior a las importaciones de 1979. En 1980 la importación de bienes de capital se redujo grandemente debido principalmente al deterioro en la producción y en la inversión, y a la fuga de capitales. Además existian problemas de financiamiento externo y hubo control más estricto de divisas que frenaron el crecimiento de las importaciones.

En 1981 y 1982 los bienes de consumo importado disminuyeron, primordialmente porque muchos de ellos se encontraban dentro de la gama de bienes de importación que habian sido prohibidos como parte de la política de austeridad del gobiemo.

En 1983 las importaciones dejaron de disminuir aún cuando la recesión económica y los problemas políticos continuaron. Los inventarios de bienes intermedios y de capital estaban depletos y para evitar una caída aún más grande en la producción se autorizó la importación de bienes que antes habian estado restringidos.

Las importaciones continuaron aumentando en 1984 debido básicamente a la expansión del crédito doméstico y a importantes medidas de liberalización implementadas a finales de 1983 y durante el transcurso de 1984.

Después de una ligera disminución en las importaciones de 1985, en 1986 los bienes importados presentan un ascenso significativo pasando de 2,403 millones de colones a $₫ 4,674$ millones, es decir un aumento del $94.51 \%$.

Es conveniente recordar que en enero de ese ano el gobiemo decide unificar el tipo de cambio a cinco colones por dólar y se eliminan ciertas restricciones a la importación.

\section{La economla salvadorena 1978 - 1985}

En este apartado veremos los principales rasgos de la economía del pals durante 1978-1985, las políticas fiscales y monetarias adoptadas por el gobiemo, y por último examinaremos el comporamiento de la inflación en El Salvador. 
Después de un período de tendencia al crecimiento en la economia que culminó con una subida extraordinaria en los precios del café en 1977, la tendencia se revierte en 1978.

En ese ano hubo una baja en el precio internacional del café y una fuerte pérdida en divisas. Desde entonces, la situación externa y los problemas domésticos generaron un colapso en la economia.

La situación socio-política llevó una baja severa en la producción, a una disminución de la inversión, y a una fuga extraordinaria de capital, junto con los danos físicos sufridos por la infraestructura debido a los atentados terroristas, el cierre de fábricas y problemas financieros. Estos hechos, junto con problemas externos como el deterioro en los términos de intercambio, la recesión económica internacional y las dificultades para obtener financiamiento externo, tuvieron un impacto decisivo en el freno a la actividad económica.

En estos anos, ocurrieorn cambios muy importantes, la Junta de Gobierno asumib el poder en 1979.

En 1980 se implementó la primera fase de la reforma agraria, se nacionalizo el sistema bancario y también se nacionalizó la comercialización externa del café y el algodón.

Por el lado de la oferta, el producto nacional bruto (PNB) en términos reales crecio $5.7 \%$ en 1978 , tasa ligeramente inferior a la observada en 1977. Pero la situación realmente se agraba durante 19791983, cuando el producto disminuye un $23.5 \%$ (Ver cuadros 1 y 2).

En efecto, el producto per-cápita cae en 1981 al nivel que tenía 20 antos atrás.' A partir de 1983 hay una ligera recuperación de la oconomla aunque a un ritmo bastante lento.

Los principales factores que contribuyeron al estancamiento de la Economia fueron las condiciones politicas inestables, la falta de financiamiento externo, la disminución en la demanda doméstica, la escasez de financiamiento para el sector privado, y la escasez de insumos extranjeros.

Por otro lado, el ligero crecimiento observado de 1983 a 1989 , puede deberse a la ayuda extranjera lograda durante esos anos, a la expansión del crédito doméstico y a ciertos incentivos otorgados mediante tasas de cambio más altas que la oficial.

Los sectores de producción que presentaron las tasas de crecimiento más altas durante 1983-1985 fueron los sectores manulactureros y de servicios, y el sector construcción en 1983 y 1985. $Y$ al contrario, la 
Cuadro No. 1

EI Salvador: Oferta total y Demanda

\begin{tabular}{|c|c|c|c|c|c|c|c|c|}
\hline & \multicolumn{8}{|c|}{ Millones de colones a precios de 1980} \\
\hline & 1978 & 1979 & 1980 & 1981 & 1982 & 1983 & 1984 & 1985 \\
\hline Oterta_onal & 13,789 & 13,385 & 11,881 & 10,928 & 9,922 & 10,122 & 10,024 & 10,339 \\
\hline -PNB & 9,860 & 9.760 & 8,917 & 8,181 & 7,723 & 7,781 & 7,896 & 8,023 \\
\hline $\begin{array}{l}\text {-lmport. de bienes } \\
\text { y servicios }\end{array}$ & 3,929 & 3,625 & 2,964 & 2,747 & 2,199 & 2,431 & 2,313 & 2,443 \\
\hline Demanda_ofal & 13,789 & 13,385 & 11,881 & 10,928 & 9,922 & 10,122 & 10,209 & 10,466 \\
\hline - Demanda doméstica & 10,781 & $9, \pi 7$ & 8,835 & 8,746 & 8,163 & 8,225 & 8,543 & 8,645 \\
\hline & 2,370 & 1,765 & 1,183 & 1,165 & 1,021 & 944 & 965 & 879 \\
\hline Fija & 2,134 & 1,714 & 1,210 & 1,110 & 973 & 910 & 924 & 973 \\
\hline Var. Invent. & 236 & 51 & (27) & 55 & 48 & 34 & 41 & (94) \\
\hline Consumo total & 8,411 & 8,012 & 7.652 & 7,581 & 7.142 & 7,281 & 7,578 & 7,766 \\
\hline Privado & 7,124 & 6.727 & 6,405 & 6,286 & 5,923 & 6,121 & 6,400 & 6,673 \\
\hline Público & 1,287 & 1,285 & 1,247 & 1,295 & 1,219 & 1,160 & 1,178 & 1,093 \\
\hline $\begin{array}{l}\text {-Exportación de bienes } \\
\text { y servicios }\end{array}$ & 3,008 & 3,608 & 3,046 & 2,182 & 1,759 & 1,897 & 1,666 & 1,821 \\
\hline Export - Import. & (921) & (17) & 82 & (565) & $(440)$ & $(444)$ & (647) & (622) \\
\hline
\end{tabular}

Fuente: International Monetary Fund, Intemational Statistics, English Yearook 1986.

Cuadro No. 2

El Salvador: Oferta total y Demanda

\begin{tabular}{|c|c|c|c|c|c|c|c|c|}
\hline & \multicolumn{8}{|c|}{ Tasa de crecimiento } \\
\hline & 1978 & 1979 & 1980 & 1981 & 1982 & 1983 & 1984 & 1985 \\
\hline Olerta Iotal, & 7.48 & (2.93) & (11.24) & (8.02) & (9.21) & $2 . .02$ & (0.28) & 2.43 \\
\hline PAB & 5.66 & $(1.01)$ & $(8.64)$ & (8.25) & $(5.60)$ & 0.75 & 1.48 & 1.61 \\
\hline $\begin{array}{l}\text {-Import. de blenes } \\
\text { y senvictes }\end{array}$ & 12.34 & (7.74) & (18.23) & $(7.32)$ & (19.95) & 6.46 & $(1.20)$ & 5.62 \\
\hline Demanda Iolal & 14.04 & (2.93) & 11.24) & $(8 . \infty 2)$ & (9.21) & 2.02 & 0.86 & 2.52 \\
\hline - Demenda domsestca & 26.30 & (8.31) & (9.63) & (1.01) & (8.67) & 0.76 & 3.87 & 1.19 \\
\hline Inv. bruta dom. & 8.41 & (25.53) & $32.87)$ & (1.52) & (12.36) & (7.54) & 2.22 & $(\mathbf{8 . 9 1 )}$ \\
\hline $\mathbf{F l j a}$ & 7.75 & (18.68) & (29.40) & (8.26) & (12.34) & (6.47) & 1.54 & 5.30 \\
\hline Ver. Invent. & 14.71 & (78.39) & (152.94) & $(303.70)$ & (12.783) & (29.17) & 20.59 & (329.27) \\
\hline Consumo btal & 32.59 & $(4.74)$ & (4.49) & $(0.83)$ & (5.79) & 1.95 & 4.08 & $2.48^{\circ}$ \\
\hline Privado & 34.53 & (5.57) & (4.79) & (1.80) & $(5.77)$ & 3.34 & 4.58 & 4.27 \\
\hline 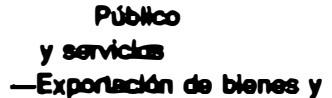 & 22.78 & $(0.16)$ & 2.96) & 2.85 & $(5.67)$ & (4.64) & 1.55 & (7.22) \\
\hline $\begin{array}{l}\text { convates } \\
\text { Expor - Import. }\end{array}$ & (15.53) & 19.85 & (15.58) & (28.37) & (19.39) & 7.85 & (12.18) & 9.30 \\
\hline
\end{tabular}

Fuente: Intemational Monetay Fund, Intemational Statistics, English Yeertook 1986. 
producción agricola empezó a declinar en 1980 cuando ocurrieron ciertos cambios institucionales y algunos problemas financieros. El único ano en que el sector agrícola creció fue en 1984, y esto debido principalmente al incremento en la producción de granos básicos.

Por el lado de la demanda, tanto el consumo como la inversión sufrieron una contracción en 1978-1982.

La baja en el consumo privado fue el resultado del deterioro de los salarios reales y del creciente desempleo o subempleo.

Desde 1983, la demanda doméstica comienza a aumentar aunque a un ritmo bastante lento, debido en gran parte al aumento del consumo doméstico que se vio fomentado por el aumento en el ingreso real y por la expansión del crédito orientado al sector privado. Además, las restricciones a las importaciones también contribuyeron a frenar el consumo de bienes extranjeros en favor de la adquisición de bienes nacionales.

Sin embargo, el escenario para la demanda de bienes de inversión no fue favorable. Durante todo el periodo 1978-1985 hubo una increfble disminución en la inversión que no pudo ser contrarestada por el relativo dinamismo que la inversión pública observó en esos anos.

Como la oferta doméstica disminuyó más 0 , según sea el caso, aumentó menos que la demanda doméstica, esta brecha fue satisfecha a través de bienes extranjeros.

Esta brecha externa entre exportaciones e importaciones disminuye en 1982 con la legalización del mercado paralelo, pero en 1984 y 1985 el déficit estaba por encima del observado en 1981. Una ligera reducción en la diferencia entre exportaciones e importaciones se observó en 1985 pero hay que recordar que en ese ano se frenó artificialmente la importación de bienes y servicios por la demora y acumulación de pagos atrasados de divisas autorizadas.

\section{Polftica crediticla}

En general a través del perlodo 1978-1985 la política monetaria expansiva mantuvo la creciente fuga de capitales y la preferencia del público por mantener activos llquidos o dólares. Problemas de liquidez aparecen en el sistema bancario.

El Banco Central expandió el crédito disponible para bancos comerciales, e implementó algunas medidas como la elevación de las tasas do interes en 1979 y 1982, y redujo las tasas de redescuento en 1979. 
No obstante estas acciones, siempre hubo limitación de fondos para financiar la reforma agraria, el déficit fiscal y el sector agricola.

Durante el perlodo 1978-1982, el crédito doméstico aumentó en términos reales, pero durante los anos 1983-1985 disminuyó a niveles inferiores al de 1981 (ver gráfica 1). Este fenómeno contrasta con la reducción y luego la ligera recuperación del PNB en esos perlodos respectivamente.

En términos nominales, el crédito doméstico estuvo creciendo a tasas decrecientes de 1980 a 1982, disminuyó en 1983, para luego empezar a elevarse a tasas crecientes.

Después de la nacionalización del sistema financiero en 1980, el crédito al sector público abruptamente excedió por primera vez, y por una considerable cantidad, los fondos otorgados al sector privado.

En particular hubo una extraordinaria expansión del crédito al sector público en 1981 y 1982 con incrementos porcentuales del $153.3 \%$ y 43.5\% respectivamente, (ver cuadro 3 ). Al mismo tiempo el crédito doméstico al sector privado bajó $7.5 \%$ en 1980 y subió únicamente $5.9 \%$ en 1981.

En 1983 hubo una pequeña reducción en el crédito de $2 \%$ (el crédito al sector público disminuyó y el crédito orientado al sector privado se elevo). Estos hechos obedeclan a los ajustes y disposiciones que el gobiemo habla convenido con el FMI. Este ano la oferta monetaria (M1) disminuyó, pero los depósitos a plazo aumentaron $48.65 \%$ favorecidos por las tasas de interés más altas.

Desde 1984, las nuevas políticas económicas estuvieron orientadas a la expansión de la demanda y a la promoción de la actividad del sector privado. El crédito doméstico aumentó $12.2 \%$ en 1984 y $19.95 \%$ en 1985.

El crédito dirigido al sector privado se elevó $26.2 \%$ en 1985 después de que habla aumentado únicamente un $10.1 \%$ el ano anterior. El crédito al sector público creció a tasas decrecientes.

Estos factores combinados con los ingresos más altos de las exportaciones de café, y con la obtención de fondos extranjeros sobre todo a través del endeudamiento externo del gobierno, permitieron la recuperación de reservas internacionales en 1983.

\section{Polftica flscal}

Cuando la crltica situación financiera del gobierno central se hizo evidente, se implementaron una serie de reformas tributarias a finales 


\section{Cuadro No. 3}

\section{El Salvador: Balance Monetarlo}

\begin{tabular}{|c|c|c|c|c|c|c|c|c|c|c|c|c|}
\hline & \multicolumn{6}{|c|}{$\begin{array}{l}\text { Saldo a fin de año } \\
\text { Millones de colones }\end{array}$} & \multicolumn{6}{|c|}{ Tasas de crecimiento } \\
\hline & 1980 & 1981 & 1982 & $1983 c$ & $1984 c$ & $1985 c$ & 1980 & 1981 & 1982 & $1983 c$ & $1984 c$ & $1985 c$ \\
\hline $\begin{array}{l}\text { Dinero (M1) } \\
\text { Dinero fuera de banc. } \\
\text { Depósitos Ctes. }\end{array}$ & $\begin{array}{r}1416 \\
719 \\
697\end{array}$ & $\begin{array}{r}1404 \\
703 \\
701\end{array}$ & $\begin{array}{r}1470 \\
732 \\
738\end{array}$ & $\begin{array}{r}1448 \\
725 \\
723\end{array}$ & $\begin{array}{r}1698 \\
835 \\
863\end{array}$ & $\begin{array}{l}2156 \\
1080 \\
1076\end{array}$ & $\begin{array}{r}7.2 \\
-3.2 \\
20.6\end{array}$ & $\begin{array}{r}-0.8 \\
-2.2 \\
0.6\end{array}$ & $\begin{array}{l}4.7 \\
4.1 \\
5.3\end{array}$ & $\begin{array}{l}-1.5 \\
-1.0 \\
-2.0\end{array}$ & $\begin{array}{l}17.3 \\
15.2 \\
19.4\end{array}$ & $\begin{array}{l}27.0 \\
29.3 \\
24.7\end{array}$ \\
\hline $\begin{array}{l}\text { Factores de expans. } \\
\text { Act. Exter. Netos } \\
\text { Crédito doméstico } \\
\text { Gobierno (neto) } \\
\text { Entidades oficiales } \\
\text { Sector Privado }\end{array}$ & $\begin{array}{r}3689 \\
-175 \\
3864 \\
418 \\
1269 \\
2177\end{array}$ & $\begin{array}{l}4255 \\
-373 \\
4628 \\
1059 \\
1133 \\
2436\end{array}$ & $\begin{array}{l}5089 \\
-197 \\
5286 \\
1520 \\
1016 \\
2750\end{array}$ & $\begin{array}{r}5526 \\
303 \\
5223 \\
1372 \\
834 \\
3017\end{array}$ & $\begin{array}{r}6180 \\
322 \\
5858 \\
1613 \\
937 \\
3322\end{array}$ & $\begin{array}{r}74655 \\
439 \\
7026 \\
1821 \\
1012 \\
4193\end{array}$ & $\begin{array}{r}10.3 \\
\overline{-} \\
27.7 \\
\overline{-} \\
121 . \overline{0} \\
-7.5\end{array}$ & $\begin{array}{r}15.3 \\
- \\
19.8 \\
153.3 \\
-10.7 \\
11.9\end{array}$ & $\begin{array}{r}19.6 \\
- \\
14.2 \\
43.5 \\
-10.3 \\
12.9\end{array}$ & $\begin{array}{r}8.6 \\
- \\
-1.2 \\
-9.7 \\
-17.9 \\
9.7\end{array}$ & $\begin{array}{r}11.8 \\
- \\
12.2 \\
17.6 \\
12.4 \\
10.1\end{array}$ & $\begin{array}{r}20.8 \\
- \\
19.9 \\
12.9 \\
8.0 \\
26.2\end{array}$ \\
\hline $\begin{array}{l}\text { Factores de absorción } \\
\text { Cuasi dinero } \\
\text { Dep. de Ahorro } \\
\text { Dep. a Plazos } \\
\text { Bonos } \\
\text { Deuda Ext. a L.P. } \\
\text { Otros (neto) }\end{array}$ & $\begin{array}{r}2273 \\
1135 \\
643 \\
492 \\
190 \\
725 \\
223\end{array}$ & $\begin{array}{r}2851 \\
1397 \\
787 \\
610 \\
205 \\
922 \\
327\end{array}$ & $\begin{array}{r}3619 \\
1633 \\
893 \\
740 \\
246 \\
1239 \\
501\end{array}$ & $\begin{array}{r}4080 \\
2004 \\
904 \\
1100 \\
263 \\
1572 \\
241\end{array}$ & $\begin{array}{r}4490 \\
2496 \\
1016 \\
1480 \\
294 \\
1518 \\
182\end{array}$ & $\begin{array}{r}5311 \\
3208 \\
1276 \\
1931 \\
246 \\
1429 \\
428\end{array}$ & $\begin{array}{r}12.4 \\
0.9 \\
8.4 \\
-7.3 \\
-21.8 \\
50.4 \\
29.7\end{array}$ & $\begin{array}{r}25.4 \\
23.1 \\
22.4 \\
24.0 \\
7.9 \\
27.2 \\
46.6\end{array}$ & $\begin{array}{l}26.9 \\
16.9 \\
13.5 \\
21.3 \\
20.0 \\
34.4 \\
53.2\end{array}$ & $\begin{array}{r}12.7 \\
22.7 \\
1.2 \\
48.6 \\
6.9 \\
26.9- \\
-51.9\end{array}$ & $\begin{array}{c}10.0 \\
24.6 \\
12.4 \\
34.5 \\
11.8 \\
-\quad 3.4 \\
-24.5\end{array}$ & $\begin{array}{r}18.3 \\
28.5 \\
25.6 \\
30.5 \\
-16.3 \\
4-5.9 \\
135.2\end{array}$ \\
\hline $\begin{array}{l}\text { M3 = M1 + Quasi- } \\
\text { money }\end{array}$ & 2551 & 2801 & 3103 & 3452 & 4194 & 5364 & 4.3 & 9.8 & 10.8 & 11.2 & 21.5 & 27.9 \\
\hline
\end{tabular}


Flgura No. 1

Componentes monetarlos.

Varlables en terminos reales

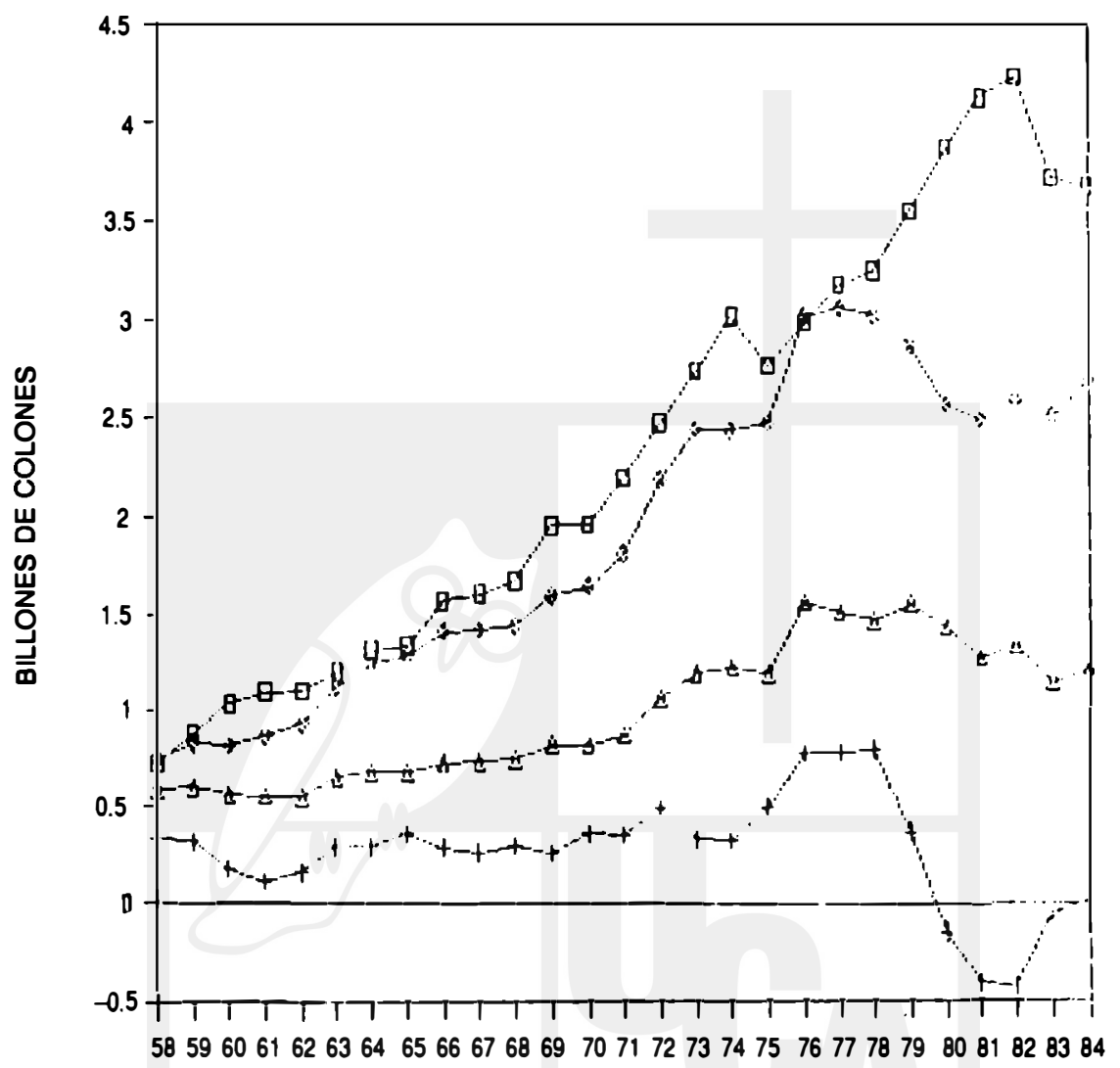

Años

D Domest. Crédito

+ Activos Extranjeros

$4 \mathrm{M} 3$

B M1 
de 1979.

Sin embargo, a pesar de estas medidas el déficit fiscal se mantuvo alto desde 1978. Después de 1980, el déficit fiscal creció en lugar de disminuir, alcanzando en 1984 los $\$ 1,108$ millones al aumentar un $79 \%$ respecto al déficit del ano anterior. Este notable aumento se atribuyó a una elevación de aproximadamente un $437 \%$ en pagos para amontizar la deuda doméstica del gobiemo.

Esta situación contribuyó a los déficit comerciales y pérdida en reservas intemacionales cuando el gobierno generó una presión hacia arriba de la demanda sin una contrapartida igual en la producción.

Diferentes factores contribuyeron al acentuamiento del déficit fiscal. Los gastos corrientes habian estado aumentando, y estos incrementos eran atribuibles más que todo a aumentos en sueldos y salarios, pagos externos y financiamiento de gastos militares.

La inversión fija aumentó de 1978 a 1980, en estos anos el gobierno sostuvo intervenciones a gran escala siguiendo políticas expansivas para promover la reactivación de la economia. En 1980 y 1984, la inversión pública alcanzo el $53 \%$ y $34 \%$, respectivamente del total de la inversión fija. En 1980, la inversión pública representó un $7.1 \%$ del producto nacional bruto, mientras que en 1984 la proporción fue únicamente del $4 \%$. Sostenidamente, durante estos anos el crédito al sector público excedió los fondos dados al sector privado.

Entre los acontecimientos que impidieron al gobierno obtener mayores ingresos corrientes estuvieron el deterioro en las ganancias del sector exportador de café y la disminución en la captación de impuestos de otros sectores cuya actividad habia decaido. Además, algunas restricciones a las importaciones sobretodo de bienes no esenciales redundó en una disminución en los ingresos del gobierno en concepto de impuestos a la importación.

Sin embargo, el gobierno logró el financiamiento del déficit, habiendo desempenado el Banco Central un papel muy importante al verse obligado a comprar los bonos emitidos por el gobierno para financiar su déficit.

No obstante, siempre fue necesario el financiamiento externo. La deuda extema aumentó un $49 \%$ en 1981 a un monto equivalente al $14.5 \%$ del PNB. El crédito generalmente se obtuvo con condiciones bastante favorables, y provino principalmente del FMI, el Banco Mundial $y$ el AID.

Los préstamos del fondo estaban sujetos a la implementación de 
medidas de liberalización en la economia, a la liberación del comercio exterior y tipos de cambio, a una racionalización de las tasas de interés y políticas de precios, a una distribución más balanceada de créditos entre el sector privado y el público, y a un enfoque más cauteloso en cuanto al manejo de la demanda. ${ }^{2}$ La mayoria de fondos del AID se orientaron al sector agrícola con énfasis en la reforma agraria.

\section{Comportamlento de la Inflación}

Si analizamos el índice de precios al consumidor es claro que (ver cuadro 4 y gráficas 2 y 3) de 1960 a 1972 la evolución de los precios fue altamente estable con incrementos anuales en los precios que no sobrepasaban el $2.8 \%$.

En 1973, la inflación fue del $6.5 \%$ para luego pasar a $16.8 \%$ en el siguiente periodo, ano en el cual la inflación se conviente en un problema económico para el país.

Si bien es cierto que para estos anos las tasas de inflación en EI Salvador, son más bajas que las que existen en la mayoria de los paises latinoamericanos, hay que considerar el impacto de este fenomeno inflacionario que surge después de un largo periodo caracterizado por la estabilidad de precios.

El proceso inflacionario resulta ser aún más grave, si consideramos: uno, el proceso inflacionario ocurre al mismo tiempo en que se da una recesión económica en el pais; dos, las tasas de crecimiento de los precios más agudas ocurren para articulos básicos sobre todo para los alimentos.

Un estudio realizado por la SIECA en 1982 senalaba que el Salvador presentaba los precios más altos para muchos artículos de consumo básico, (huevos, leche, frijoles), comparado con los precios existentes en el resto de naciones centroamericanas. ${ }^{3}$

En 1980 es notorio la aceleración de la tasa de inflación que alcanzo un $17.4 \%$ comparado con un $14.7 \%$ un ano antes. Las categorias que sufrieron los incrementos más altos fueron los alimentos $(20 \%)$ y la ropa (17\%).

Tuvo mucho que ver en este aumento de precios en 1980, las grandes expansiones de la oferta monetaria, a través de aumentos en el crédito doméstico, que ocurrieron en 1979 y 1980.

La expansión del crédito doméstico en ese ano resultó básicamente del financiamiento del déficit fiscal que en 1980 aumentó en la alarmante proporión de $445.1 \%$. Esta expansión de la oferta monetaria a través del crédito doméstico no alcanzó niveles más altos debido a la 
Cuadro No. 4

Indice de preclos al consumldor y tasa de Inflación 1958-1985

\begin{tabular}{lccccc}
\hline Anos & $\begin{array}{c}P \\
1980=100\end{array}$ & $\begin{array}{c}\text { Inflación } \\
(\%)\end{array}$ & Anos & $\begin{array}{c}P \\
1980=100\end{array}$ & $\begin{array}{c}\text { Inflación } \\
(\%)\end{array}$ \\
\hline 1958 & 34.3 & & 1972 & 37.0 & 1.65 \\
1959 & 34.1 & $(0.58)$ & 1973 & 39.4 & 6.49 \\
1960 & 34.0 & $(0.29)$ & 1974 & 46.0 & 16.75 \\
1961 & 33.1 & $(2.65)$ & 1975 & 54.8 & 19.13 \\
1962 & 33.1 & 0.00 & 1976 & 58.7 & 7.12 \\
1963 & 33.6 & 1.51 & 1977 & 65.6 & 11.75 \\
1964 & 34.2 & 1.79 & 1978 & 74.3 & 13.26 \\
& & & & & \\
1965 & 34.4 & 0.58 & 1979 & 85.2 & 14.67 \\
1966 & 34.0 & $(1.16)$ & 1980 & 100.0 & 17.37 \\
1967 & 34.5 & 1.47 & 1981 & 114.0 & 14.00 \\
1968 & 35.4 & 2.61 & 1982 & 128.3 & 12.54 \\
1969 & 35.3 & $(0.28)$ & 1983 & 145.3 & 13.25 \\
1970 & 36.3 & 2.83 & 1984 & 162.1 & 11.56 \\
1971 & 36.4 & 0.28 & 1985 & 198.2 & 22.27
\end{tabular}

Fuente: International Monetary Fund. International Financial Statistics. English Yearbook 1986.

Banco Central de Reserva de El Salvador Revista Mensual, enero-febrero 1986.

pérdida de reservas internacionales, originada a su vez de ese exceso de of erta monetaria.

Este hecho impidió que los precios crecieran aún más, ya que parte de la demanda doméstica fue satisfecha en mercados extranjeros.

Otros problemas económicos, como la caída del crédito al sector privado y el aumento de los precios del petróleo en 1979, también contribuyeron al proceso inflacionario. Por otro lado, los problemas politicos y las reformas institucionales implementadas en 1980, generaron acciones especulativas, problemas de distribución y escasez de oferta sobre todo de granos básicos.

La situación llegó a un punto tal, que a finales de 1980 el gobierno emite la "ley de estabilización temporal", con la que se pretendia combatir la inflación. 
Flgura No. 2

Indice de preclos al consumldor

$1980=1$

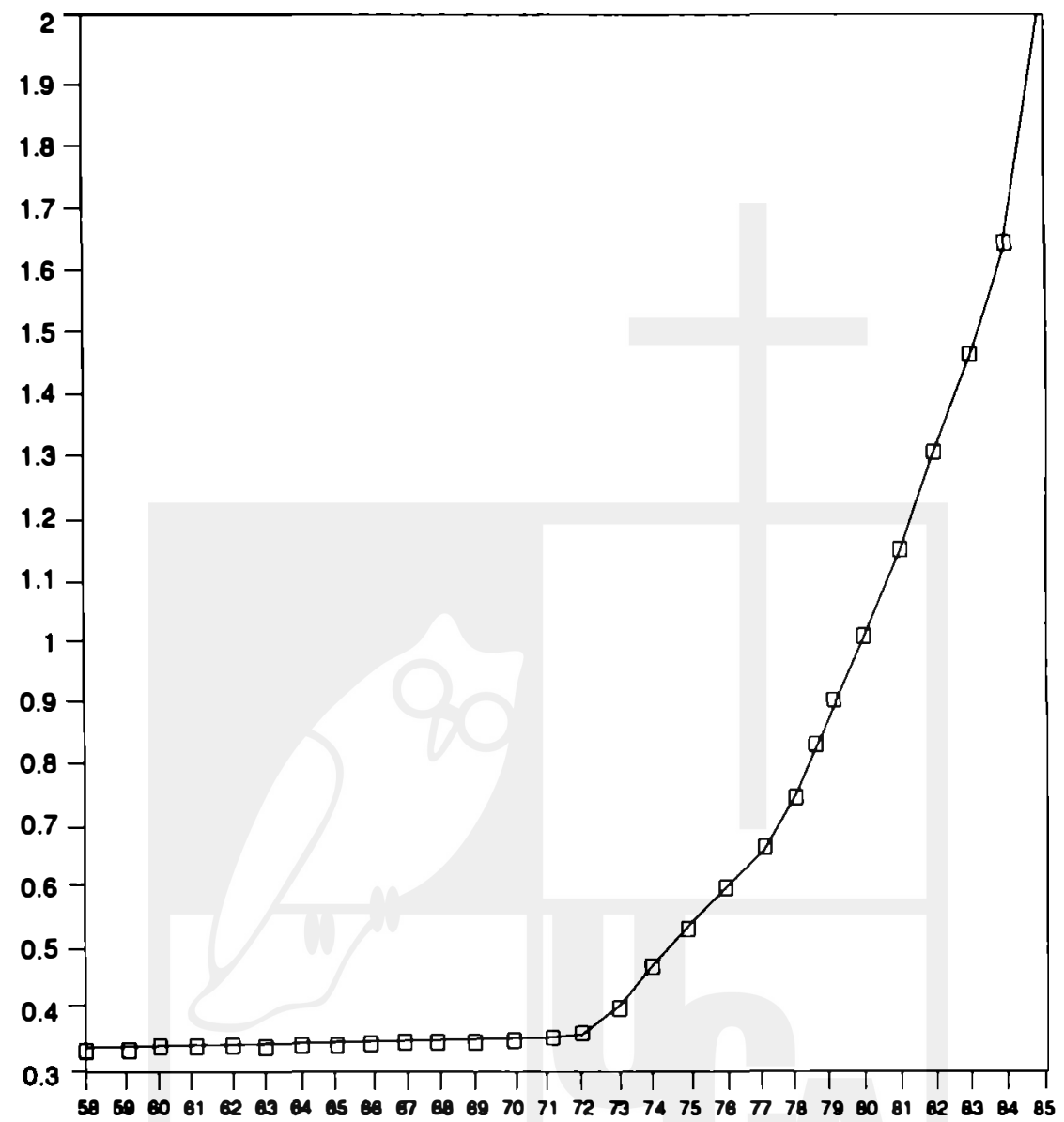

Años

Entre las medidas adoptadas como parte de este programa de estabilización se encontraban las referentes a la regulación del comercio y de los precios de bienes alimenticios básicos, servicios médicos y alquileres; el establecimiento de techos de precios para ciertos productos estratégicos, el congelamiento de los sueldos y salarios de los empleados públicos y de sus beneficios sociales.

Después de 1980 , la inflación pasa de $17.37 \%$ en ese ano a $14.00 \%$ 
Flgura No. 3

Tasa de crecimlento del dinero e Inflación

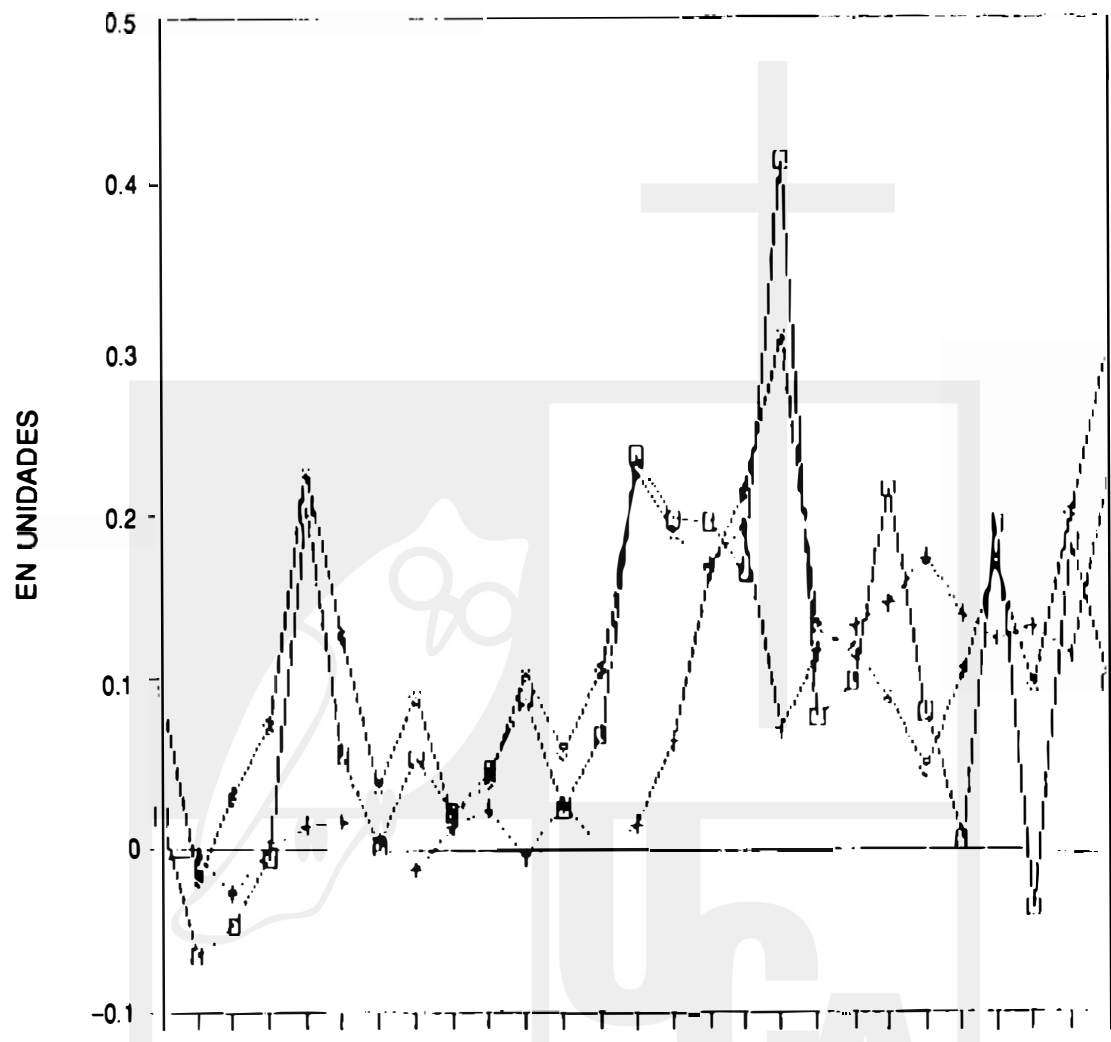

$596061626364656667686970717273747576 \quad 77787980 \quad 8182838485$

Años

v M2 Tasa de Crecimiento $\quad$ Inflación

M3 Tasa de

crecimiento 
en 1981 y $12.54 \%$ en 1982 . Hay un ligero aumento en 1983 con una inflación del $13.25 \%$ pero esta cae a $11.56 \%$ en 1984 es decir presenta un nivel más bajo incluso que la inflación que existia en 1977.

Sin embargo, este escenario tan favorable se revierte completamente en 1985, cuando la tasa de inflación alcanzada es de. $22.3 \%$, el doble de la tasa del ano anterior. Este ano coincide con expansiones sustanciales en la oferta monetaria, y con las medidas adoptadas por el Banco Central de trasladar la venta de divisas al mercado paralelo para prácticamente todos los bienes importados.

A esto anádase que en estos momentos prevalecen las expectativas de una inminente devaluación.

IV. Controles a las transacclones que Involucran compra-venta de moneda extranjera 1978-1986

Las regulaciones cambiarias son manejadas psor el Banco Central a través de su departamento de control de cambios, bajo las directrices y controles emitidos por la Junta Monetaria

Cuando el mercado paralelo se crea en agosto 16 de 1982, la aprobación de la mayoria de pagos en ese mercado fue delegada a los bancos comerciales, aunque era indispensable la autorización previa del Departamento de Control de Cambios.

En cuanto a los controles al comercio intemacional estos han sido ejercidos básicamente por el Banco Central, el Ministerio de Economia y el Ministerio de Agricultura.

Asl en la década de los 80 todas las importaciones y exportaciones valuadas en $\$ 200.00$ o más necesitaban un certificado de registro de importación o exportación emitido por el Banco Central.

El ministerio de Economia, a través de un convenio con el Ministerio de Agricultura, estaba a cargo de emitir licencias de exportación y de importación para algunos articulos que asl lo requerian.

Bajo la administración del Partido Demórata Cristiano, la comercialización del café y del azúcar estuvo supeditada al Instituto Nacional del Café (INCAFE) y al Instituto Nacional del Azúcar (INAZUCAR).

\section{Princlpales controles camblarlos emitldos durante 1978 y 1986}

En vista de la diffcil situación que habla experimentado el sector externo desde 1978, incluyendo una abrupta y significativa calda en reservas internacionales, la Junta Monetaria implementó a partir de 1980 varias restricciones a la venta de divisas. 
En primer lugar, se estableció el control estatal de las ventas de café y algodón, y se creó el Ministerio de Comercio Exterior. En segundo lugar, se introdujeron una serie de enmiendas a la "ley de control de transferencias Internacionales" (promulgada en 1961). Se hizo obligatoria la declaración de cualquier cantidad de moneda extranjera que ingresara 0 saliera del pais y asimismo cualquier ingreso de divisas debia ser entregado al Eanco Central para que este pagara en colones el monto recibido. Cualquier venta de dólares requeria la autorización previa del Banco Central. La infracción a cualquiera de estas medidas daba lugar a sanciones y multas aunque estas no puede decirse que fueron impuestas a cabalidad.

Bienes de importación considerados como no esenciales, y que antes de 1980 requerian un $100 \%$ de depósito, vieron elevar este a un $200 \%$, además se introdujo un depósito del $100 \%$ para otros bienes que antes no lo requerian.

Simultáneamente, se prohibió la importación de algunos bienes no esenciales que provinieron de afuera del área centroamericana.

La venta de divisas para estudiantes en el extranjero, gastos de viaje, gastos médicos u hospitalarios, fue reducida, y las remesas para ayudas familiares se suspendieron.

Sin embargo, a finales de 1980 las drásticas medidas implementadas fueron suavizadas un poco al permitir que personas que residieran en el extranjero pudieran mantener cuentas de no residentes en divisas cuyos fondos podian utilizar libremente. Simultáneamente se autorizó a los residentes la apertura de depósitos en divisas cuyos fondos provinieran de exportaciones no tradicionales hacia paises que no estuvieran en la región centroamericana, o cuyos fondos provinieran de companias extranjeras o del turismo.

La transferencia de fondos entre las dos clases de cuentas descritas anteriormente fue prohibida. Los fondos de depósitos en moneda extranjera de los residentes podian ser vendidos únicamente a los bancos dentro del mercado paralelo, o podlan utilizarse para el pago de bienes o importaciones de servicios, y para pagos mensuales hasta de $\$$ 2,000.00 en concepto de remesas a estudiantes, viajes, ayuda familiar, educación, tratamientos médicos y otros pagos personales.

En 1981 se introdujeron regulaciones concemientes al pago de "invisibles". Se autorizó la venta de dólares para remesas a empleados públicos que estuvieron becados en el exterior, o para estudiantes con becas otorgadas por organismos intemacionales.

Además se autoriza de nuevo, aunque con clertos IImites, remesas 
en concepto de pensiones. Se otorgaron fondos para pagos médicos y hospitalarios aunque sujetos a un depósito del $100 \%$.

A finales de ano, se suspendió la venta de moneda extranjera en el mercado oficial para estudiantes que a esa fecha no estuvieran registrados con el departamento de control de cambios, pero al mismo tiempo se autorizó utilizar fondos de las cuentas en dólares para esta clase de pagos.

Durante el ano de 1981 empezaron a acumularse demoras en los pagos debido a que la escasez de divisas no pudo superarse pese las restricciones introducidas en los últimos anos. Es asi como en 1982 se reurre a cambios más fundamentales en la política cambiaria, como es la transformación del sistmea de tipo de cambio en el pais con la legalización del mercado paralelo en agosto de $1982 .{ }^{4}$

La legalización del mercarto paralelo fue acompanada de sanciones más drásticas sobre aquellas transacciones de dólares ilegales. Con esto se perseguia canalizar las operaciones de divisas a través de los mercados legales: el oficial y el paralelo.

V. Sistema de tlpo de camblo, el mercado paralelo y el mercado negro en El Salvador

El Salvador ha establecido la paridad del colón salvadoreno con el dólar desde 1919, cuando el tipo de cambio se fijó en $\$ 2.00$ por $\$ 1.00$. Esta paridad fue modificada en 1934 a $\$ 2.50$ por $\$ 1.00$, la cual tue ratificada en 1944 cuando el Fondo Monetario Internacional es creado.

El Salvador está integrado al sistema monetario internacional y es una de las naciones que se suscribieron originalmente al Fondo Monetario y al Banco Mundial. Ambos organismos fueron creados en la conferencia de Bretton Woods ocurrida en New Hampshire, en julio de 1944.

La tasa unificada de $\$ 2.50$ por $\$ 1.00$ prevaleció hasta 1982 , fecha en la cual la escasez de divisas llevó al establecimiento del mercado paralelo pasándose asi, por primera vez, de un sistema de tipo cambio único y fijo a un sistema de tipo de cambio múltiple donde habria espacio para cierta fluctuación en el valor del dólar.

\section{El mercado paralelo}

E mercado paralelo, que venla funcionando informalmente desde flnales de 1981, se legaliza en agosto de 1982, debido a la escasez de divisas que continua pese a las medidas adoptadas por el gobienro a fin de aumentar la captación de dólares. 
En el mercado oficial el tipo de cambio permaneció fijo a $\$ 2.50$ por $\$ 1.00$. La tasa que se establecía en el mercado paralelo se concibió inicialmente, al menos en el papel, como la tasa resultante de la acción de las fuerzas libres de oferta y demanda en le mercado de divisas.

Simultáneamente con la creación del nuevo mercado cambiario, los bancos comerciales y el hipotecario fueron autorizados a comprar y vender dólares que provinieran o se utilizaran en operaciones permitidas. Las transacciones en este mercado se registraban por aparte y se reportaban periódicamente al Banco Central. Un impuesto de $0.1 \%$ se aplicó a toda venta de moneda extranjera.

El promedio del tipo de cambio paralelo durante agosto de 1982, fue de $\$ 3.68$ por $\$ 1.00$ (ver cuadro 5). Este precio esta un $47 \%$ arriba de la tasa oficial de $₫ 2.50$ por $\$ 1.00$.

Durante el tiempo en que el mercado paralelo funcionó, el tipo de cambio (colones por dólar) fue gradualmente elevado por los bancos comerciales (ver cuadro 5). Se pretendia que la tasas de cambio en el mercado paralelo presentara un nivel más realista que el oficial que habia prevalecido hasta ahora, sin embargo, el tipo de cambio en este mercado dual siempre estubo muy por debajo de el que prevalecia en el mercado negro.

Los principales afectados con este diferencial fueron los exportadores de los principales productos de exportación al verse obligados a vender sus ingresos por exportación a un precio para el dólar extremadamente bajo.

El primer ano, la proporción del saldo de la balanza comercial que se gestionó a través del mercado paralelo fue del $15.5 \%$. En 1983, la proporción llegó a $18.9 \%$ y alcanzó el nivel de $75.22 \%$ en 1984 .

Desde un principio se persiguió que sólo aquellas transacciones consideradas prioritariás para el bienestar de la nación se efectuaran en el mercado oficial. Asl tenemos que originalmente se gestionó en el mercado oficial la compra y venta de medicinas, materia prima, fuentes de energia, exportaciones tradicionales y algunos pagos invisibles entre los cuales estaban pagos por interés y en concepto de dividenobs.

Inicialmente, la venta de dólares en el mercado paralelo era destinada a la compra de bienes no esenciales, servicios de importación, gastos de viaje, ayuda familiar, gastos de estudio y manutención, servicios médicos y hospitalarios y otros pagos invisibles personales. Además, se podian obtener divisas adicionales en el mercado paralelo para el pago de servicios unilaterales y de invisibles, para la amortización de 
Cuadro No. 5

Tasas de camblo mensuales en el mercado paralelo 1982 - 1985

\begin{tabular}{|c|c|c|c|c|c|c|c|c|c|c|c|c|}
\hline & Compra & $\begin{array}{c}1982 \\
\text { Venta }\end{array}$ & 2 promed. & Compra & $\begin{array}{c}1983 \\
\text { Venta }\end{array}$ & promed. & Compra & $\begin{array}{l}1984 \\
\text { Venta }\end{array}$ & Promed. & Compra & $\begin{array}{c}1985 \\
\text { Venta }\end{array}$ & Promed \\
\hline $\begin{array}{l}\text { Enero } \\
\text { Febrero } \\
\text { Marzo } \\
\text { Abril } \\
\text { Mayo } \\
\text { Junio } \\
\text { Julio } \\
\text { Agosto } \\
\text { Septiembre } \\
\text { Octubre } \\
\text { Noviembre } \\
\text { Diciembre }\end{array}$ & $\begin{array}{r}- \\
- \\
- \\
- \\
- \\
- \\
- \\
3.61 \\
3.87 \\
3.98 \\
3.88 \\
3.73\end{array}$ & $\begin{array}{r}- \\
- \\
- \\
- \\
- \\
- \\
- \\
3.74 \\
3.92 \\
4.04 \\
4.01 \\
3.83\end{array}$ & $\begin{array}{r}- \\
- \\
- \\
- \\
- \\
- \\
3.68 \\
3.90 \\
4.01 \\
3.95 \\
3.78\end{array}$ & $\begin{array}{l}3.76 \\
3.84 \\
3.90 \\
3.91 \\
3.91 \\
3.93 \\
3.95 \\
3.95 \\
3.95 \\
3.95 \\
3.96 \\
3.95\end{array}$ & $\begin{array}{l}3.77 \\
3.93 \\
3.97 \\
3.97 \\
3.98 \\
4.00 \\
4.04 \\
4.04 \\
4.03 \\
4.02 \\
4.04 \\
4.04\end{array}$ & $\begin{array}{l}3.77 \\
3.89 \\
3.94 \\
3.94 \\
3.95 \\
3.97 \\
4.00 \\
4.00 \\
3.99 \\
3.99 \\
4.00 \\
4.00\end{array}$ & $\begin{array}{l}3.95 \\
3.89 \\
3.86 \\
3.87 \\
3.95 \\
3.95 \\
3.95 \\
3.96 \\
3.95 \\
3.95 \\
3.96 \\
3.98\end{array}$ & $\begin{array}{l}4.03 \\
4.02 \\
2.96 \\
3.96 \\
4.02 \\
4.04 \\
4.03 \\
4.02 \\
4.02 \\
4.02 \\
4.02 \\
4.06\end{array}$ & $\begin{array}{l}3.99 \\
3.96 \\
3.91 \\
3.92 \\
3.99 \\
4.00 \\
3.99 \\
3.99 \\
3.99 \\
3.99 \\
3.99 \\
4.02\end{array}$ & $\begin{array}{l}3.99 \\
4.02 \\
4.03 \\
4.04 \\
4.05 \\
4.21 \\
4.44 \\
4.75 \\
4.73 \\
4.81 \\
\text { n.a. } \\
\text { n.a. }\end{array}$ & $\begin{array}{l}4.06 \\
4.08 \\
4.08 \\
4.10 \\
4.13 \\
4.26 \\
4.46 \\
4.77 \\
4.67 \\
4.80 \\
\text { n.a. } \\
\text { n.a. }\end{array}$ & $\begin{array}{l}4.03 \\
4.05 \\
4.06 \\
4.07 \\
4.09 \\
4.24 \\
4.45 \\
4.76 \\
4.70 \\
4.81 \\
4.90 \\
4.90\end{array}$ \\
\hline Promedio anual & & & 3.86 & & & 3.95 & & & 3.98 & & & 4.42 \\
\hline $\begin{array}{l}\text { Proporción en la } \\
\text { balanza comercia } \\
\text { Paralelo } \\
\text { Oficial }\end{array}$ & & & $\begin{array}{l}5.50 \% \\
4.50 \%\end{array}$ & & & $\begin{array}{r}1983 \\
18.90 \% \\
81.10 \%\end{array}$ & & & $\begin{array}{r}1984 \\
75.22 \% \\
24.78 \%\end{array}$ & & & \\
\hline tasa promedio & & & 2.71 & & & 2.77 & & & 3.61 & & & \\
\hline
\end{tabular}

n.a.: no disponible

$\because$ no inclye petróleo

Fuente: - Banco Central de Reserva de el Salvador, Departamento de Inv.

- FADES de C.A., "Análisis Económico", $1985-1986$ publicación semanal. 
ciertas inversones extranjeras, para elevar los saldos de cuentas autorizadas en moneda extranjera o para ventas de divisas interancarias.

Habla límites en cuanto la cantidad de dólares que podian ser vendidas para gastos de viajes y gastos personales, pero no habia limite para la venta de dólares para gastos médicos o para estudios.

Por el lado de la recepción de divisas, los bancos podlan adquirirlas pagando la tasa vigente en el mercado paralelo si los fondos provenian de exportaciones no-tradicionales, remesas familiares, comisiones y pagos por servicios personales y por último también podian venderse en el mercado paralelo fondos provenientes de cuentas en moneda extranjera o que provinieran de otros bancos comerciales.

La autorización del departamento de control de cambios era necesaria para obtener divisas en el mercado paralelo, sin embargo, para analizar la eficiencia del mercado paralelo - tal como se verá más adelante- es necesario tener en cuenta que la aprobación de divisas por parte del departamento de control de cambios de ninguna manera significaba que habla disponibilidad de divisas en el mercado paralelo, es más, en este perlodo empiezan a acumularse significativamente retrasos en el otorgamiento de dólares ya autorizados.

Este último hecho es una manifestción más de que todas las medidas tendientes a contraer la demanda de dólares y a elevar la oferta de los mismos, hablan tenido muy poco éxito. La captación de divisas en estos anos simplemente no era suficiente para satisfacer la demanda de estos fondos. Esta escasez de divisas frenó en cierta medida las importaciones, pero este freno, puede decirse que se logró "artificialmente" pues no corresponde a un estado donde la demanda de divisas haya sido satisfecha, sino más bien fue producto de la escasez de las mismas con todas las consecuencias que esto implica para el crecimiento económico en un país altamente dependiente de sus importaciones.

No obstante la pérdida de reservas internacionales que acompanó a la escasez de divisas, una serie de medidas de liberalización cambiaria fueron implementadas durante 1983. Estas acciones estaban en la linea de los compromisos contraídos con el FMI a través del de préstamos condicionados que este organismo habla otorgado al pais.

Una gran proporción de artículos fueron transferidos del mercado oficial al mercado paralelo. Incluso, algunos bienes no esenciales que hablan sido prohibidos desde 1980 fueron autorizados ahora a través del mercado paralelo. 
Los ingresos provenientes de exportaciones de café hacia nuevos mercados, y una proporción del valor de las exportaciones de algodón y camarón estaban entre la nueva clase de fondos que podian convertirse a la tasa vigente en el mercado paralelo. Además, toda transacción que tuviera que ver con comisiones, regalias, repatriación de inversión extranjera y dividendos, también podian efectuarse a través del mercado paralelo.

Las divisas continuaron siendo insuficientes pero las importaciones crecieron durante 1983 después de decrecer por tres anos consecutivos. Este crecimiento de las importaciones tuvo básicamente dos motivos: primero, el ablandamiento de los controles relacionados con las transacciones de divisas y la suspensión de algunas restricciones; segundo, las firmas habian estado agotando en estos anos sus inventarios ante la imposibilidad de obtener divisas, y por tanto es de esperar que hubiera llegado el momento en que no podian postergar aún más, al menos no sin serias consecuencias, la reposición del inventario usado.

La ayuda extranjera hizo posible que aumentara el nivel de reservas internacionales pero no logró satisfacer completamente la demanda.

A principios de 1984, se establecieron tratos preferenciales para la importación de bienes y servicios provenientes del área centroamericana. Estos privilegios se centraron principalmente en las importaciones de Costa Rica y Guatemala. Sin embargo, los incentivos para esta clase de importaciones fueron suspendidos a finales de ano. Por otro lado, la venta de divisas para bienes de importación se pasaron del mercado oficial al mercado paralelo incluyendo algunas importacones de Centro América.

A.lgunas medidas menos restrictivas referentes a la importación de automóviles también fueron introducidas en 1984. Sin embargo, en diciembre de ese mismo ano se adoptaron medidas más restrictivas con respecto a la importación de algunos bienes intermedios y de todos los productos qulmicos (exceptuando medicinas, fertilizantes e insecticidas), pués el $50 \%$ del valor de estas importaciones eran divisas que deberian obtenerse al tipo de cambio del mercado paralelo.

En junio de 1985, el financiamiento de la mayoría de bienes intermedios se transfirió al mercado paralelo, y el requerido para ciertos bienes fue suspendido. Básicamente sólo permanecieron en el mercado oficial algunas medicinas y sus insumos, fertilizantes, insecticidas y sus insumos, el petróleo, equipo médico-quirúrgico y algunas materias primas. 
Con respecto a las exportaciones a mediados de ano, todos los ingresos en divisas de exportaciones no tradicionales fueron autorizadas para ser vendidas en el mercado paralelo. Igualmente toda la exportación de algodón de la última cosecha y la exportación de camarón fueron vendidas al tipo de cambio dual. Se aumentó los límites de las cantidades de ingresos provenientes de la exportación de café y azúcar que podia ser convertida fuera del mercado oficial.

Otras regulaciones que afectaron los pagos e ingresos de invisibles, fueron también introducidas ese ano. Por otro lado, todo ingreso proveniente de servicios brindados o de la entrada de capital privado se efectuaria en el mercado paralelo. Como puede observarse, hubo una transferencia gradual -bastante acelerada en este último ano- de las operaciones que pasaron de ser realizadas en el mercado paralelo.

Ante la imposibilidad de solventar los desequilibrios del sector externo, cuyo problema más inmediato o más claro era la escasez de divisas, las autoridades pretendieron lograr una devaluación gradual del colón salvadoreno a través del mercado paralelo.

El 21 de enero de 1986, la Junta Monetaria estableció la unificación del tipo de cambio a la tasa de $\$ 5.00$ por $\$ 1.00$ dando fin a la existencia del mercado paralelo.

\section{El mercado negro}

El llamado "mercado negro" de divisas surge en el pais en abril de 1961, cuando se prohibe por ley transacciones privadas de oro o de divisas.

En diciembre de 1961, el precio del dólar era de $\$ 3.25$ por $\$ 1.00$ (ver cuadro 6 figura 4). En 1964-1965 la moneda salvadorena se fortalece cuando el precio del dólar disminuye a $\$ 2.60$. Desde entonces, el dólar continúa fluctuando entre $₫ 2.60$ y $\$ 2.44$, hasta que en octubre de 1974, los rumores de una devaluación ${ }^{5}$ hacen que el precio ascienda a $\$ 3.00$ por $\$ 1.00$.

Después de un corto período de recuperación de la tasa se devalua de nuevo a $₫ 3.05$ en agosto de 1975. Desde entonces, las wondiciones políticas y económicas adversas propician una fuerte fuga de capitales y mantienen el precio del dólar bastante elevado.

A mediados de 1978 el precio de la divisa alcanza los $₫ 3.00$ para llegar a $₫ 3.90$ en diciembre de 1979, cuando los rumores de una posible devaluación se hacen cada vez más fuertes. En 1980, coincidiendo con una serie de reformas estructurales, el promedio anual del tipo de cambio fue de $₫ 4.77$ por $\$ 1.00$, equivalente a un aumento del $44 \%$ 


\section{Cuadro No. 6 \\ Preclo del dólar en el mercado negro en El Salvador \\ Colones por dólar al final del mes}

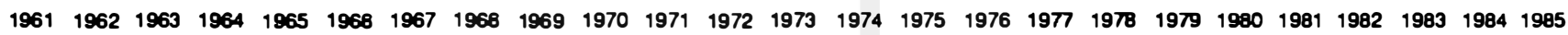

\begin{tabular}{|c|c|c|c|c|c|c|c|c|c|c|c|c|c|c|c|c|c|c|c|c|c|c|c|c|c|}
\hline Enero & 2.50 & 3.50 & 3.00 & 3.00 & 2.60 & 2.71 & 285 & 2.94 & 2.94 & 2.94 & 2.93 & 2.94 & 2.94 & 2.94 & 2.94 & 3.00 & 3.23 & 3.30 & 3.05 & 4.00 & 5.00 & 5.00 & 5.00 & 4.20 & 4.23 \\
\hline Fetrero & 2.50 & $3 ; 55$ & 3.00 & 2.90 & 2.60 & 2.60 & 2.85 & 2.94 & 2.93 & 2.95 & 2.93 & 2.94 & 2.90 & 2.94 & 2.94 & 2.90 & 3.35 & 3.30 & 3.00 & 4.00 & 8.00 & 6.00 & 5.10 & 4.00 & 4.75 \\
\hline Marzo & 2.50 & $3 ; 6$ & 3.00 & 925 & 2.65 & 2.85 & 2.85 & $2 . .95$ & 2.92 & 2.95 & 2.94 & 2.94 & 2.94 & 2.94 & 2.94 & 2.66 & 3.30 & 3.00 & 3.10 & 4.50 & 4.80 & 4.50 & 5.85 & 4.15 & 4.60 \\
\hline Abrll & 3.00 & 3.60 & 3.15 & 3.00 & 2.70 & $2 . .60$ & 2.85 & 2.90 & 2.94 & 2.94 & 2.94 & 2.94 & 2.94 & 2.94 & 2.94 & 3.00 & 3.35 & 2.95 & 3.10 & 4.20 & 5.00 & 4.00 & 5.00 & 4.15 & 5.20 \\
\hline Mayo & 3.10 & $3 ; 50$ & 3.10 & 3.00 & 2.60 & 2.85 & 2.95 & 2.94 & 2.80 & 2.94 & 2.83 & 2.94 & 2.92 & 2.94 & 2.94 & 3.00 & 3.50 & 3.00 & 3.15 & 6.00 & 5.20 & 4.40 & 5.20 & 4.15 & 5.45 \\
\hline Junto & 3.12 & 3.50 & 3.15 & 2.95 & 2.75 & 2.87 & 2.80 & 2.94 & 2.94 & 2.95 & 2.94 & 2.94 & 2.92 & 2.94 & 2.99 & 3.05 & 3.35 & 2.90 & 3.15 & 6.25 & 4.50 & 4.70 & 6.00 & 4.15 & 5.80 \\
\hline Jullo & 3.10 & 3.30 & 3.20 & 2.85 & 2.70 & 2.60 & 2.98 & 2.80 & 2.95 & 2.94 & 2.94 & 2.94 & 2.94 & 2.94 & 2.98 & 3.00 & 3.40 & 2.95 & 3.20 & 6.50 & 4.75 & 4.55 & 6.00 & 4.30 & 6.10 \\
\hline Aoosto & 3.25 & 3.20 & 3.15 & 2.85 & 2.70 & 2.80 & 2.94 & 2.92 & 2.95 & 2.94 & 2.94 & 2.94 & 2.94 & 2.94 & 3.05 & 3.05 & 3.40 & 3.00 & 3.20 & 4.25 & 5.55 & 4.70 & 6.55 & 4.30 & 6,50 \\
\hline Sopt. & 3.30 & $3 . .25$ & 3.12 & 2.95 & 2.70 & $2 . .90$ & 2.94 & 2.91 & 2.94 & 2.93 & 2.94 & 2.94 & 2.94 & 2.94 & 3.00 & 3.03 & 3.35 & 3.05 & 3.35 & 4.10 & 5.00 & 5.00 & 6.00 & 4.30 & 8.50 \\
\hline Oct. & 3.33 & 3.30 & 3.05 & 2.70 & 2.70 & 2.85 & 2.94 & 2.92 & 2.95 & 2.94 & 2.94 & 2.94 & 2.94 & 2.94 & 3.00 & 3.23 & 3.35 & 3.01 & 3.60 & 4.15 & 4.75 & 5.20 & 5.05 & 4.30 & 6.57 \\
\hline Nov. & 3.45 & 3;25 & 3.11 & 2.60 & 2.70 & 2.88 & 2.94 & 2.92 & 2.94 & 2.94 & 2.94 & 2.94 & 2.94 & 3.00 & 3.03 & 3.13 & 3.30 & 3.03 & 3.60 & 4.30 & 4.45 & 5.40 & 4.80 & 4.30 & 6.70 \\
\hline $\begin{array}{l}\text { Prom. } \\
\text { anual }\end{array}$ & 3.00 & 3.39 & 3.10 & 2.85 & 2.69 & 2.80 & 2.91 & 2.93 & 2.94 & 2.94 & 2.94 & 2.94 & 2.93 & 2.95 & 2.98 & 3.04 & 3.35 & 3.04 & 3.30 & 4.77 & 5.13 & 4.87 & 5.45 & 4.23 & 5.91 \\
\hline
\end{tabular}

Fuente: World Currency Yearbook, Brooklyn, N.Y., 1984

Centro de Investigaciones Económicas (CIE), "Correo Económico". 
Flgura No. 4

Tipo de camblo en el mercado negro

Colones por dólar

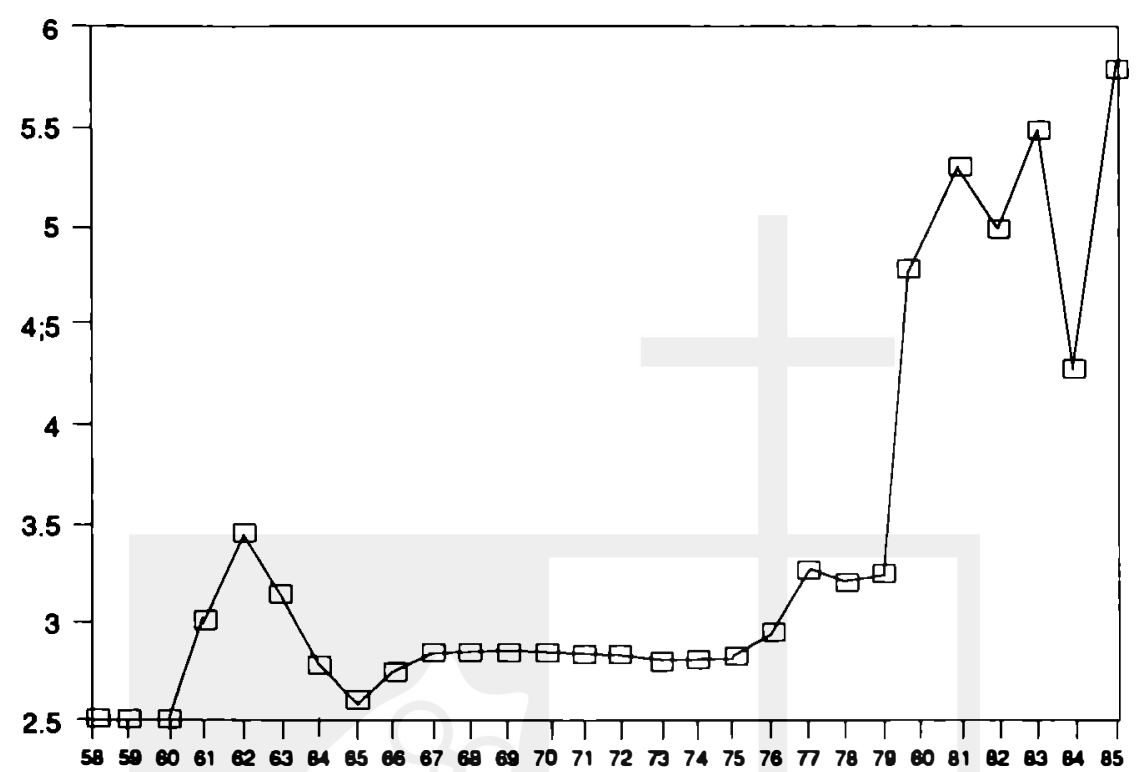

Años

cuando se compara con el promedio anual del año anterior.

Sin embargo, el tipo de cambio más alto en el mercado negro se alcanza en febrero de 1981, cuando el dólar registra el precio record de \$8.00. No obstante, el tipo de cambio promedio anual de ese ano aumentó únicamente un $75 \%$ cuando se compara con la tasá promedio del ano anterior.

La tendencia al alza observada en el precio del dólar en este mercado, se revierte en 1982 cuando se crea el mercado paralelo, produciéndose una apreciación del $5 \%$ en la tasa promedio anual. Sin embargo, para 1983 el tipo de cambio habia superado el vigente en 1981 a una tasa de depreciación del $12 \%$, con un precio promedio de $₫ 5.45$.

El 1984 hubo un descenso en el valor de la divisa comparada con anos anteriores, (ver cuadro 6) siendo el precio promedio anual de $\$ 4.23$ menor incluso que el promedio para 1980 en 1985. No obstante, cuando se introducen medidas de liberación cambiaria y hay una mayor participación del mercado paralelo en las transacciones internacionales, 
junto con los rumores persistentes de una próxima devaluación, el dólar vuelve encarecerse alcanzando en diciembre de 1985 el monto de c6.50.

En el primer quinquenio de los ochenta, no sólo hay una mayor fluctuación del precio del dólar (con una tendencia al alza) en el mercado negro, sino también la actividad en él se incrementa considerablemento.

Pese a la ilegalidad de las transacciones, muchas familias encuentran su modus-vivendus en este mercado al mismo tiempo que se convierte en un medio de enriquecimiento de otras, junto a los fuertes rumores de que altos funcionarios están involucrados en el mismo.

El campo de operaciones del mercado ilegal se concentra sobre todo en los alrededores del centro de gobierno, convenientemente ubicado en las proximidades de las oficinas de Correo.

Pese a las multas y castigos que establece la ley respecto a este tipo de compra-venta de divisas, numerosas personas se dedican a la vista de todos a este negocio, disputándose los clientes que acaban de recibir dólares a través de correo o a los numerosos automovilistas que llegaban al lugar a transar divisas. En una red bastante organizada los especuladores de dólares prosperan, pese a alguno que otro asalto en el lugar de Ide los hechos.

\section{Marco teórico}

En este apartado se presentarán diferentes enfoques teóricos para ontender las fluctuaciones macroeconómicas en economias pequenas y abiertas como la de EI Salvador.

Primero se analizaran los saldos de la Balanza de Pagos de acuerdo a tres enfoques diferentes: el de la elasticidad, el de la absorción y el monetario, incluyendo una explicación de las consecuencias de la devaluación de acuerdo a cada enfoque. Luego se desarrollará un modelo de comercio intemacional para EI Sa Ivador, enfatizando en una situación donde el tipo de cambio está sobrevaluado, el desempleo os alto y la sustitución de bienes domésticos por bienes importados es baja.

Al final, se analiza el mercado de divisas, sefialando las consecuenclas del desequilibrio en este mercado dentro de un sistmea de tipo de cambio fijo. 


\section{Dlferentes enfoques a la balanza de pagos}

Si hay un déficit en la balanza de pagos se asume que existe sobrevaluación de la moneda doméstica. En el caso de EI Salvador, esto significará que el precio del dólar es demasiado bajo comparado con el precio que lograria el equilibrio en el mercado de divisas.

Esta sobrevalación significaría que hay un exceso de demanda doméstica que es satisfecha en gran parte con bienes extranjeros.

El efecto inmediato de una devaluación será un aumento en el precio en colones de las importaciones. Esto conduce al encarecimiento de los precios de bienes producidos intemamente pero que necesitan insumos importados o bienes intermedios importados, esta elevación de los precios de estos artículos tendrá efectos colaterales que se traducirán en la elevación de precios del resto de artículos, generando un alza general en el nivel de precios.

El cambio en el precio relativo de los bienes comerciables y no comerciables se espera que cambiará la demanda en favor de los artículos no comerciables y en beneficio de la producción de bienes comerciables. Esto mejorará la balanza de pagos a través de una reducción de las importaciones y de un aumento de las exportaciones.

El aumento en el nivel general de precios reducirá los saldos reales y por consiguiente es probable que la gente reduzca su gasto para restaurar sus saldos reales originales.

Esto traerá un efecto favorable en la balanza de pagos a través de la disminución en el gasto en bienes importados y bienes exportables La reducción en la oferta de saldos reales aumentará la tasa de interés incentivando asi la entrada de capitales con lo que también se ayuda a restaurar el equilibrio en la balanza de pagos.

La balanza de pagos usualmente se explica a través de 3 enfoques diferentes pero complementarios:

- el enfoque de la elasticiad

- el enfoque de la absorción

- el enfoque monetario

El enfoque de elasticiad de la balanza de pagos trabja con la ecuación de la balanza comercial:

$$
B C=X-M
$$

Aqui el énfasis esta sobre los efectos que un cambio exógeno, di- 
gamos el tipo de cambio, tiene sobre las exportaciones y las importaciones y en consecuencia sobre la balanza comercial.

De acuerdo a un caso particular de este enfoque, la devaluación tendrá un efecto positivo sobre la balanza de pagos si se cumple la condición "Marshall-Lerner" la cual requiere que la elasticidad de demanda doméstica por importaciones más la elasticidad de la demanda extranjera por las exportaciones del pais sea mayor que uno. El éxito de la devaluación depende sobre todo de las variaciones de las exportaciones e importaciones en respuesta a variaciones en sus precios.

En el enfoque de absorción, desarrollado por Alexandere, se usa la identidad del ingreso nacional en una economía abierta:

$$
Y=C+I+(X-M)
$$

de manera que:

Donde $(X-M)$ es la balanza comercial, $Y$ es el ingreos nacional, $C$ es el consumo doméstico.

I es la inversión doméstica y $(C+$ I) es el gasto doméstico llanıdo también absorción (A).

La balanza comercial se considera igual a la diferencia entre el ingreso nacional y el gasto doméstico total.

Aqul una devaluación mejorarla la balanza comercial únicamente si el ingreso aumenta más que el gasto.

La devaluación af ectará la cuenta corriente de tres maneras diferentes:

1. Aumentando el ingreso nacional debido al incremento en la producción de bienes de exportación.

2. Aumentando el gasto debido al incremento del ingreso (propensión marginal a gastar).

3. Por los efectos directos sobre la absorción a través del cambio en saldos reales derivados de precios más altos, redistribución del ingreso e ilusión monetaria.

El tercer enfoque de la balanza de pagos es el enfoque monetario que considera el saldo de la balanza de pagos como cambios en las reservas intemacionales mantenidas por el Banco Central, es decir, que lo considera como un fenómeno monetario.

El total de activos del sistema bancario se considera dividido en reservas internacionales y otros activos que representan el crédito doméstico. La suma de estas dos clases de activo es igual a la ofenta 
monetaria.

$$
M=R+D
$$

Donde $M$ es la oferta monetaria medida a través de $M 3, R$ son las reservas internacionales y $D$ es el crédito doméstico.

Cambios en las reservas internacionales son equivalentes a cambios en el déficit o superavit de la balanza de pagos, to que a su vez es equivalente a la diferencia entre los cambios en saldos reales y los cambios en el crédito doméstico (creación de crédito adicional por el sistema bancario total):

$$
\mathrm{A}=\mathrm{B}=\mathrm{M}-\mathrm{D}
$$

Donde B es la balanza de pagos.

Un déficit en la balanza de pagos resultará de un exceso de oferta monetaria sobre la demanda. La gente para deshacerse de ese exceso estará dispuesta a gastarlo en bienes, servicios u otros activos.

Por el contrario cuando tenemos un superavit en la balanza de pagos lo que tenemos es un exceso de demanda de saldos reales sobre la oferta, la gente reduciria su gasto en relación al ingreso en orden a acumular saldos reales, bajo un sistema de tipo de cambio fijo, la oferta monetaria es una varialbe endógena. Las autoridades pueden manejar la parte de la oferta monetaria respaldada por el crédito doméstico, pero es el público el que determina los cambios en reservas intemacionales, y por tanto, los cambios en la oferta monetaria a través del ajuste de saldos reales.

El incremento de precios que producirá una devaluación reducirá la oferta de saldos reales. La gente reducirá su gasto en bienes con el objeto de restaurar sus saldos reales. Esto conducirá a una balanza de pagos superavitaria y a un aumento de la oferta monetaria.

En el caso de un país pequeno, los efectos de una devaluación sobre la reasignación de recursos y sobre los cambios en la demanda, tienen que ser considerados cuidadosamente, teniendo presente las características peculiares de la tecnologia en estos paises.

En El Salvador, las bajas elasticidades de sus exportaciones y de sus importaciones hace dudoso que se mejore la balanza comercial. El pais no tiene la capacidad de cambiar los precios intemacionales de sus exportaciones. Es más, la cantidad de exportaciones está determinada en gran medida fuera del pais a través del sistema de cuotas. 
Con un mercado de capitales poco desarrollado, no es de esperar que tasas de interés más altas se traduzcan en una mayor atracción de capitales extranjeros. Por otro lado, con la no existencia de un verdadero sector sustitutivo de importaciones, la disminución de las importaciones de algunos bienes sólo puede ser hecha a costa de un descenso en la producción.. Con la devaluación, las importaciones de bienes de consumo pueden incluso aumentar si simultáneamente con esta medida se eliminan las restricciones a la importación entonces vigentes.

Asi, si el sector manufacturero considerado comunmente como productor de articulos que compiten con las importaciones depende en gran medida de materia prima importada y bienes intermedios que no pueden ser producidos internamente, una devaluación podría llevar a una baja en la producción de este sector, tal como se ilustra en las gráficas 5.1 y 5.2 desarrolladas por Diaz Alejandro. ${ }^{7}$

Como Diaz Alejandro senala pueden darse dos casos respecto al sector manufacturero. Primero, cuando el sector se caracteriza como un sector realmente competitivo de bienes importados, una devaluación aumentará la producción de este sector. En el segundo caso, si las firmas manufactureras pertenecen a un sector que puede considerarse productor de bienes no comerciables, una devaluación tendrá un impacto negativo en el déficit comercial. Estas dos situaciones se ilustran en las gráficas siguientes:

En la figura 5.1 tenemos dos clases de bienes de importación: bienes de consumo importados (C), que compiten con la producción del

Figura 5.1 Manufacturas productor de importables

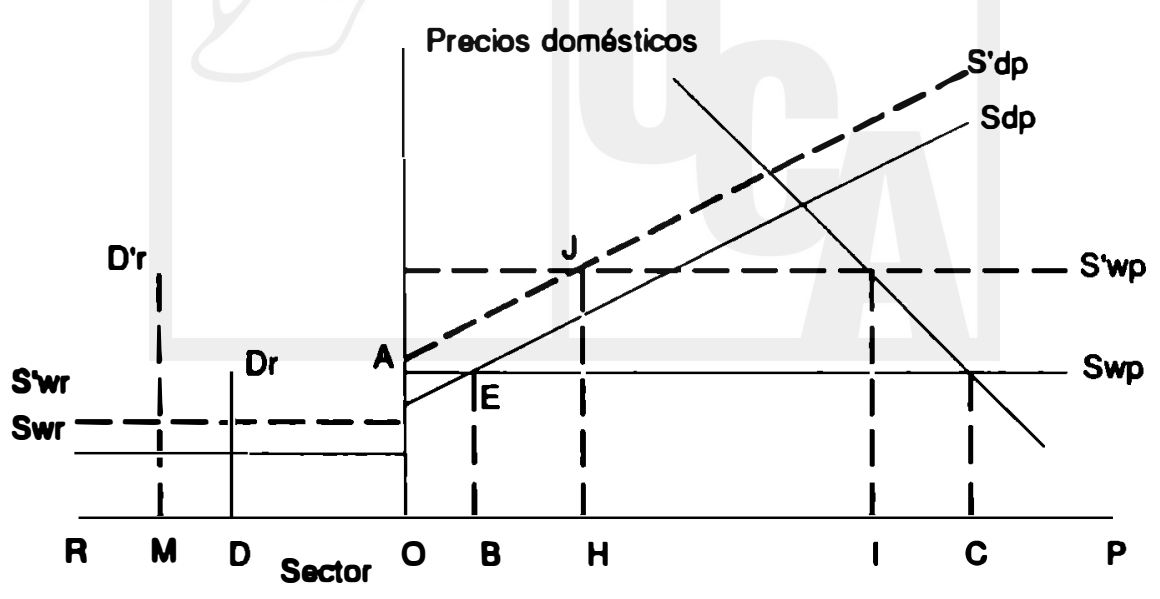


Figura 5.2 Manufacturas productor de no comerciables

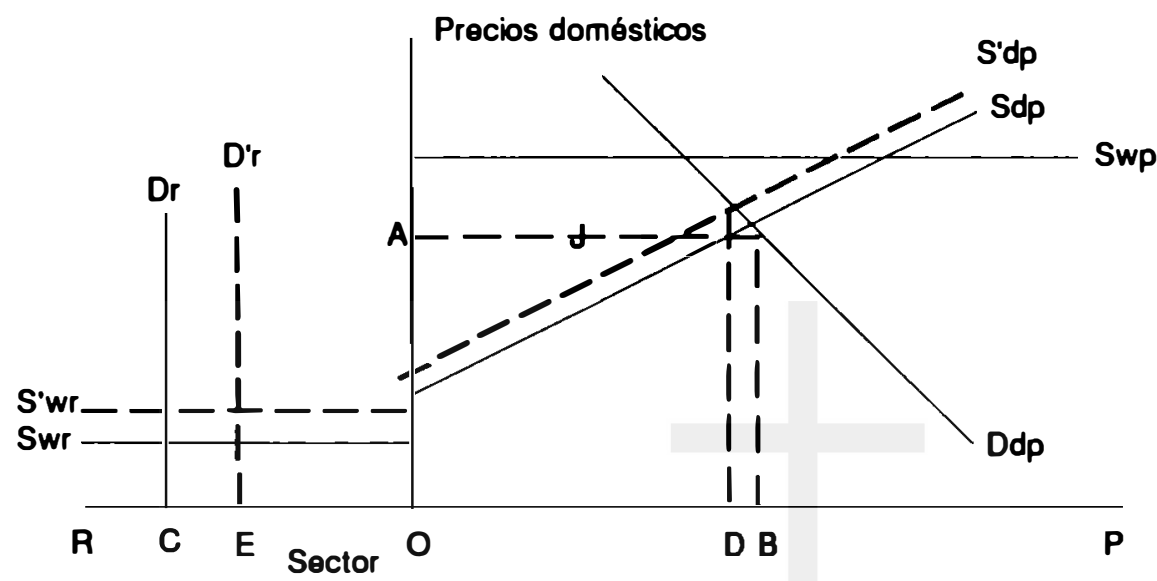

bien $P, y$ bienes intermedios importados $(R)$ que no tienen sustitutos porque no pueden ser producidos internamente. Para un tipo de cambio especifico, las curvas Ddp. Swp y Sdp corresponden a las curvas de demanda doméstica, oferta internacional y oferta doméstica para el bien $P$. La producción doméstica de $P$ para esa tasa de cambio es igual a $O B$, y genera la curva $D_{A}$ de demanda por insumos importados R. Esta última demanda es inelástica para cualquier precio dentro del rango O-A porque no hay sustitutos. La curva de oferta mundial de $R$ es SwR.

Una devaluación desplazarla hacia arriba las curvas Swp. SwR y Sdp a $S^{\prime} w R$ y S'wR y S'dp respectivamente. Esta útima curva se desplazarla debido al incremento en el precio de los insumos $\mathbf{R}$.

La producción dorriéstica de $\mathrm{P}$ aumenta una cantidad igual a BH (ver gráfico 5.1), y hay una calda en el consumo de los bienes importados $\mathbf{C}$ (sustituto de $\mathbf{P}$ ) igual a IC. Las importaciones de $\mathbf{R}$ aumentan cuando la curva de demanda se desplaza a $D_{1}^{\prime}$ como resultado del aumento en la producción doméstica del bien $P$, pero el efecto agregado es una sustitución neta por importaciones.

Sin embargo, si existen tarifas $u$ otras restricciones sobre las importaciones de $\mathbf{P}$ que hagan el precio de estas importaciones extremadamente altas, el bien $P$ pasa a ser producido en el pals sin que existan sustitutos a través de las importaciones. En este caso, una devaluación, tal como se ilustra en la Figura 5.2, desplazaria la curva Sdp a S'dp al incrementarse los costos de los insumos. Las importaciones de 
R disminuyen una cantidad igual a CE debido a que cae la producción del bien P por la cantidad DB y debido a que no hay sustitutos para este factor de producción.

\section{Un modelo de economla ablerta para El Salvador}

El Salvador es un pals agricola en el sentido que sus principales productos de exportación son agrlcolas. Sus importaciones son principalmente materia prima y bienes intermedios, la mayoria de ellos bienes esenciales en la producción del sector manufacturero. Esta clase de bienes de importación representaban un $64.3 \%$ del producto nacional bruto del sector manufacturero en 1984.

La mayorla de estos bienes importados no pueden ser producidos internamente por limitaciones en la existencia de recursos, falta de tecnologla y falta de mano de obra capacitada. Para todo tin práctico podemos decir que no hay un verdadero sector competidor de importaciones.

La figura 6 es una representación gráfica de un modelo que permite cambios en la relación de precios en moneda nacional de bienes no comerciables y de las importaciones.

El volumen de exportaciones se mide en la parte superior del eje vertical, el volumen importado se mide en la parte oeste del eje horizontal, el volumen de bienes de consumo importado se muestra en la sección sur del eje vertical,y el volumen de bienes no comerciables en la parte este del eje horizontal.

La IInea Ix, en el cuadrante noroeste indica el nivel de importaciones requerido para producir las exportaciones. Esta IInea esta bastante inclinada lo que indica que el sector exportador no necesita de grandes cantidades de bienes importados. La cantidad OB, son las importaciones de bienes de consumo importados independientemente del nivel de producción del sector exportador. Asl la IInea IC relaciona las importaciones requeridas para la producción de bienes de exportación más la Importación de bienes de consumo (esta última hemos dicho es una cantidad fija) con los diferentes niveles de producción del sector exportador.

En el cuadrante sureste se presenta la combinación de bienes de consumo Importado y de no comerciables que se consumen en el país. La combinación exacta (punto D) se determina donde la línea, ayya pendiente sea igual a los precios relativos entre bienes no comerciables y bienes de consumo importados, sea tangente a una curva de indiferencia. 
Flgura 6 Modelo con tasa de camblo sobrevaluado

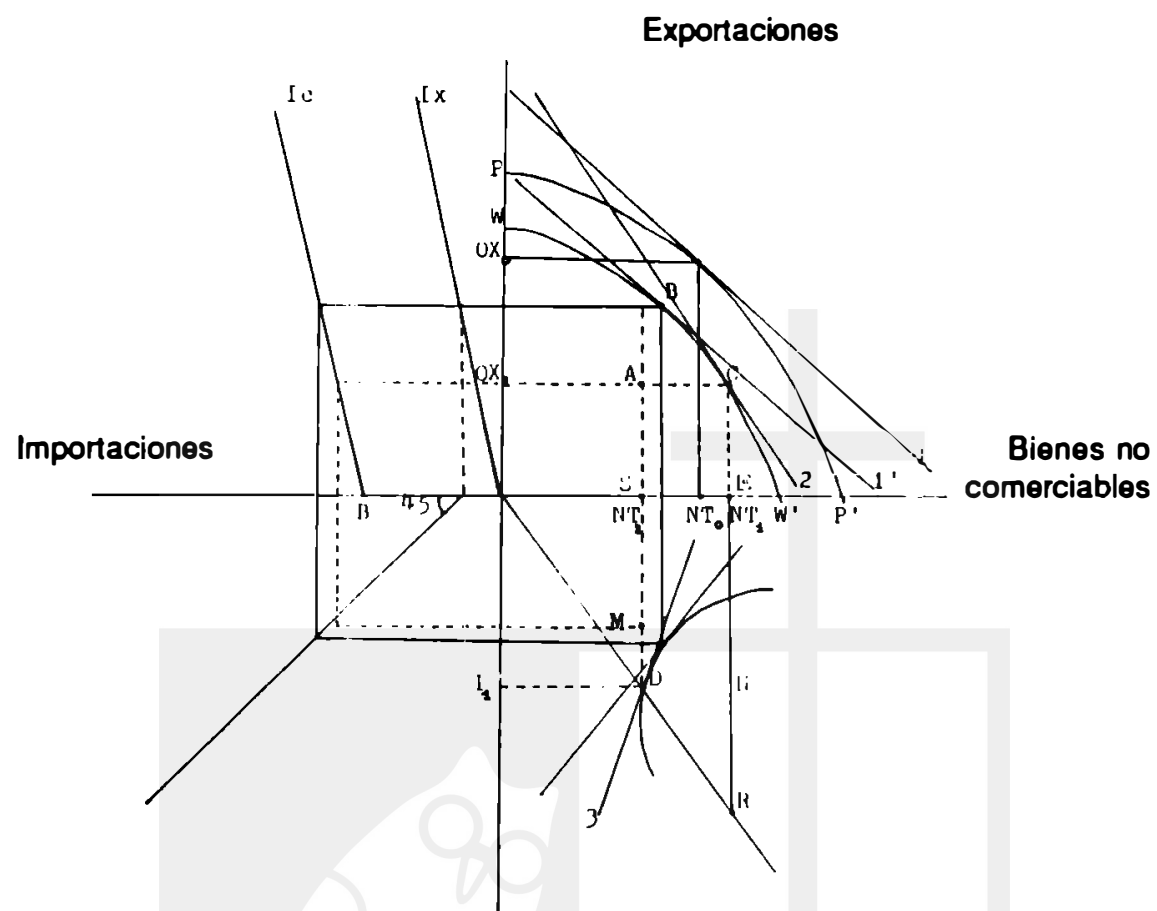

Bienes de consumo importados

La producción de bienes no comerciables y de las exportaciones: la combinación de producción de ambos tipos de bienes viene dada por el punto de tangencia entre la IInea cuya pendiente es igual a los precios relativos entre exportaciones y bienes no comerciables, y una curva de posibilidades de producción.

Se asume que no hay producción doméstica de importaciones ni consumo doméstico de bienes de exportación. Este último supuesto ayuda a simplificar el modelo sin distorcionar los resultados del mismo dada la baja producción que representa el consumo de bienes exportables en el consumo agregado doméstico.

pp' es la curva de posibilidades de producción cuando todos los recursos existentes estan siendo utilizados. Si la tasa de cambio de equilibrio determinara los precios relativos mostrados en la pendiente de la línea 1, el pais produciría NTo de bienes no comerciables y producirla y exportaría OXo.

Sin embargo, en El Salvador los recursos no estan siendo utilizados 
completamente. En 1983 existla una tasa de desempleo igual a un $30 \%$. Este desempleo estructural puede relacionarse con la existencia de salarios minimos, la especulación, incertidumbre política, las condiciones de guerra, la falta de financiamiento, etc.

Es factble, por tanto, $\infty$ nsiderar que el pais produce sobre la curva WW' que corresponde a una situación de desempleo.

La pendiente de la línea 2 corresponde al precio relativo de bienes de exportación y bienes no comerciables dado por un tipo de cambio sobrevaluado. La producción la determina el punto $C$, con NT, de bienes no comerciables y OX, de bienes de exportación, sobre la curva WW. Igualmente, el consumo deseado estará en $D$ con $I$, bienes de consumo y NT 2 bienes no comerciados. Los recursos se han trasladado hacia la producción de bienes no comerciables (de B a C) debido a los mejores precios de estos bienes que genera la sobrevaluación de la moneda. Pero la demanda de importaciones aumenta mientras decrece la demanda de bienes no comerciables que gracias a la sobrevaluación son más caros en relación a las importaciones.

Hay un exceso de demanda de importaciones igual a MD (ver gráfi$\infty$ 6), y un excaso de oferta de no comerciables igual a SE. La pendiente de la línea 3 en el cuadrante Sur-este es igual a los precios relativos entre bienes de consumo importados y bienes no comerciables correspondientes a la tasa de cambio sobrevaluada.

La situación en $C$ con un exceso de oferta de bienes no comerciables y un déficit en la balanza comercial tendria que regresar al equilibrio a través de uno de dos posibles caminos.

En el primer caso, el precio nominal de los bienes no comerciables caerla para restaurar el equilibrio en ese mercado. Los precios relativos entre las exportaciones y los no comerciables alcanzaria de nuevo el valor inicial con la producción en B (ver gráfico 6). Para que esto ocurra, la oferta monetaria tendrla que decrecer via los déficits en la balanza de pagos. Este mecanismo de ajuste no es muy bien visto por las autoridades porque implica la pérdida de reservas internacionales. Además, si los salarios se ajustan lentamente a la declinación de la demanda, el exceso de oferta de bienes no comerciables puede estar asociada con un aumento considerable en el corto plazo de desempleo.

El camino alternativo hacia el equilibrio no requiere de la calda en el precio de los no comerciables y por tanto no produciria un aumento en el desempleo. Un exceso de oferta monetaria puede existir en la economla si al mismo tiempo se implementan políticas crecientes de gasto. La demanda por bienes comerciables y no comerciables se aumentaria 
en la medida que los consumidores traten de deshacerse del exceso de balances monetarios. Esto aliviaria el exceso de oferta de los bienes no comerciables pero acentuaria el exceso de demanda por importaciones.

\section{Desequillibrlo en el mercado de dlvisas}

Los déficit de la balanza de pagos también pueden analizarse a través del mercado de divisas. El tipo de curvas de oferta y demanda extranjera viene determinado por el comportamiento de las importaciones, exportaciones y movimientos de capital. La demanda de importaciones y la salida de capital generan demanda de divisas, y la demanda extranjera por nuestros bienes nacionales o la entrada de capital equivalen a oferta de dólares. Si hay equilibrio en la balanza de pagos hay equilibrio en el mercado de divisas.

El tipo de cambio es el precio que prevalece en el mercado de divisas, y es el que conecta los sistemas de precios de diferentes paises. En un sistema de tipo de cambio fijo, el tipo de cambio lo fijan las autoridades monetarias. En El Salvador tanto el tipo de cambio de \$2.50 por dólar que prevalecia en el mercado oficial y el tipo de cambio establecido en el mercado paralelo no correspondian al precio de equilibrio del dólar y se ha requerido de la intervención de las autoridades. Sin embargo, esta intervención no pudo evitar las distorciones en el mercado que se manifestaron principalmente en una escasez creciente de divisas.

En la figura 7, el tipo de cambio de equilibrio es eo, pero la tasa oficial está por debajo de ese valor, digamos $e_{0}-a$. Hay un exceso de demanda de dólares $Q_{2}-Q_{0}$. En orden a mantener la tasa oficial las autoridades pueden recurrir a sus reservas internacionales para proveer $Q_{2}$ $-Q_{0}$ dólares a cambio de $\left(e_{0}-a\right)\left(Q_{2}-Q_{0}\right)$ colones. La oferta de dólares se desplaza a la derecha a S'. El problema aqul es que las reservas son limitadas. Si hay déficits persistentes en la balanza de pagos, esto podrla agotar las reservas y se tendrá que recurrir a otras políticas que lograrán aumentar la captación de divisas.

En el caso de El Salvador, se impusieron restricciones cuantitativas a las importaciones, sin embargo, el creciente gasto público y las expansiones en la oferta monetaria hicieron que estas restricciones fallaran en su objetivo de corregir el desbalance interno. Se tuvo que recurrir al endeudamiento externo y se permitió que el nivel de reservas bajara en forma alarmante.

Cuando el mercado paralelo fue puesto en operación, las autoridades monentarias, artificialmente lograron que las compras de divisas en 
Flgura No. 7

Mercado de dlvisas

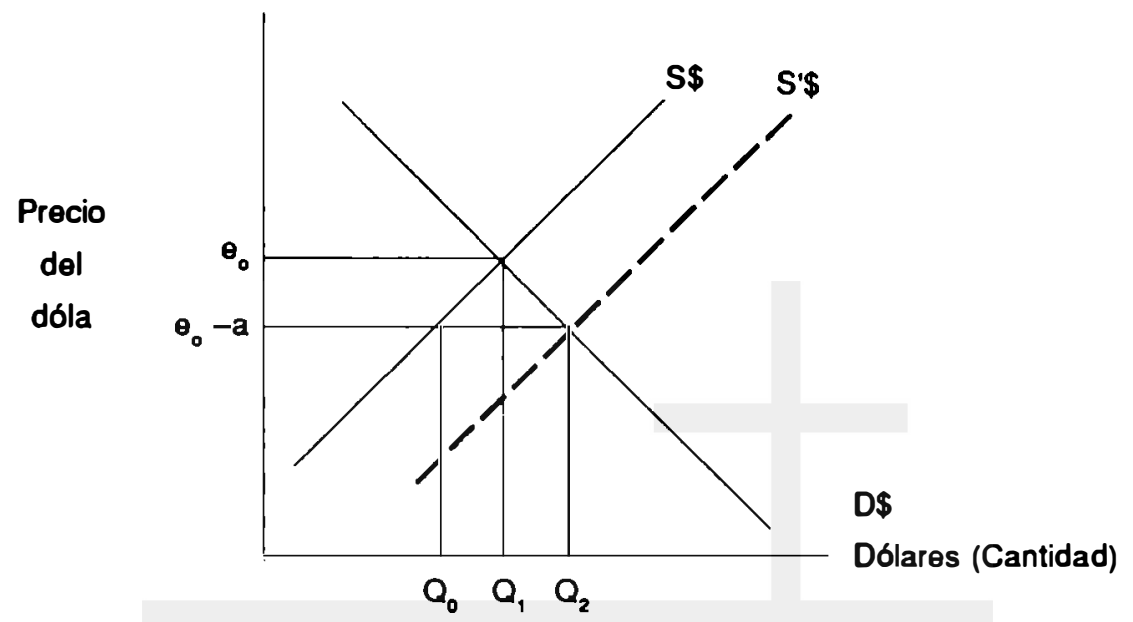

el mercado fueran mayor que las ventas a través de restricciones respecto a las operaciones que requerian divisas que podian ser adquiridas en este mercado teoricamente. Con las bajas elasticidades que presenta la demanda por nuestras exportaciones y nuestra demanda por importaciones, era necesario una devaluación considerable para resolver el déficit. ${ }^{\circ}$. (Ver gráfica 8 ).

\section{El funclonamlento del mercado paralelo en El Salvador}

En este apartado examinaremos algunas de las consecuencias de la existencia de un mercado dual en El Salvador. En primer lugar, se verá la efectividad del mercado paralelo en cuanto a la captación de divisas, eficiencia operativa y generación de ingresos fiscales. Luego se verán algunos de los efectos que un tipo de cambio sobrevaluado tiene sobre las importaciones y las exportaciones. Finalmente se presenta un sistema de ecuaciones simultáneas para medir econométricamente el efecto en variaciones en el tipo de cambio del mercado paralelo y del mercado negro sobre el volumen de exportaciones, sobre el volumen de importaciones y sobre el nivel de precios domésticos.

\section{Adminlstraclón del mercado paralelo e Ingresos flscales generados por este slstema}

El mercado paralelo se caracterizó por variaciones discrecionales en el tipo de cambio, fijado por los bancos comerciales y no por las fuerzas del mercado. Como consecuencia este tipo de cambio siempre 
Figura No. 8

\section{Devaluación con elastlcldades altas}

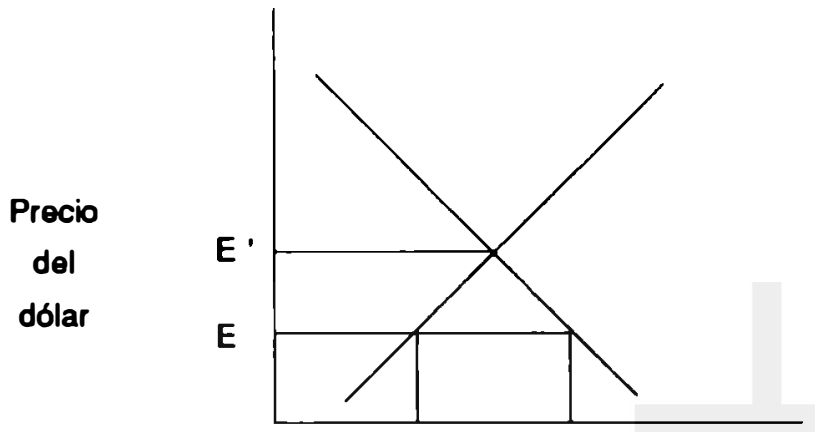

Dólares (Cantidad)

Devaluación con elastlcldades bajas

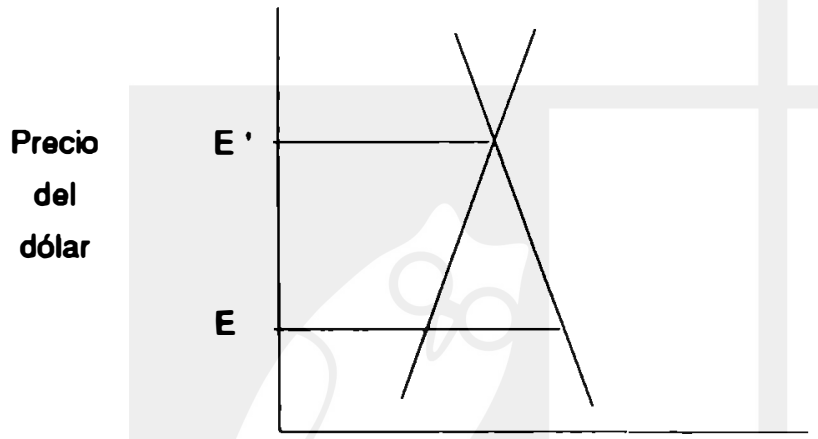

Dólar (Cantidad)

$E=$ Tipo de cambio después de la devaluación

$E^{\prime}=$ Tipo de cambio antes de la devaluación

estuvo por debajo del precio del dólar que prevalecía en el mercado negro.

El sistema no era complejo en el sentido que, en cualquier punto en el tiempo, habia sólo una tasa de cambio de compra y una de venta tanto en el mercado oficial como en el paralelo, con un pequento margen de diferencia entre estos precios de compra y venta a excepción del ano 1983.

El sistmea se complicaba un poco si se considera que habia una serie de clasificaciones de las transacciones (tanto de las que requerian como de las que generaban divisas) que podian efectuarse en el mercado paralelo o en el mercado oficial, esta lista de operaciones variaba constantemente sobre todo en los últimos tiempos de la existencia del sistema dual. Es más, en algunos momentos los ingresos de 
exportación o requerimientos de divisas para importación de un mismo artículo se vendian u obtenian en ambos mercados (paralelo y oficial) de acuerdo a porcentajes decretados.

Una de las posibles ventajas que se mencionan de tipo de cambio múltiple es su mayor facilidad de manejo en relación a los controles cuantitativos. Sin embargo, en el caso salvadoreno, los procedimientos administrativos no fueron rápidos ni efectivos, siendo una de las causas principales de esta inoperatividad no tanto la complejidad en cuanto a la clasificación de operaciones sino un hecho mucho más difícil de resolver: la escasez de divisas.

Durante la existencia del mercado paralelo se acumularon una gran cantidad de divisas que aunque ya estaban autorizadas, no se otorgaron en la práctica por la falta de disponibilidad de las mismas. En el cuadro 7 podemos notar la creciente demora en los pagos. Si las reservas internacionales hubieran sido estimadas descontando estos pagos, el nivel de estas hubiera sido mucho menor que la cifra oficial presentada.

Ante estos inconvenientes, era práctica común en estos tiempos que los importadores aplicaran por divisas con mayor anticipación (generalmente sobrefacturando) ante la lentitud del proceso, o que se recurriera al mercado negro como medida obligada (el precio de adquisición del dólar era mucho más alto en este mercado) ante la urgencia de contar con dólares.

Los productores calculaban el costo del componente importado de sus productos en base al costo de la divisa en el mercado negro, incluso con cierto margen por encima de este, ante las expectativas que el precio del dólar subiera en el corto plazo. Asi pues, la inseguridad de obtener divisas a través del mercado paralelo y las expectativas de una devaluación entre otros, hicieron que el nivel de precios se elevara más de 10 que en realidad subla el costo para los productores. Uno de los posibles beneficios de la existencia de tasas privilegiadas para ciertas importaciones, cual es evitar un excesivo incremento en el costo de articulos considerados esenciales, era pués, en buena parte anulado ya que el tipo de cambio paralelo no era parámetro a considerar en la estimación de costos.

No es muy aventurado decir, que la fuerte fuga de capitales a que dio inicio la inestabilidad política fue en parte financiada a las tasas preferenciales existentes en el mercado oficial o en el mercado paralelo (al compararlas con el precio del dólar en el mercado negro) sobre todo cuando se facturaba un mayor volumen de importaciones que las que realmente se efectuaban o cuando aparecia facturado un valor menor 
Cuadro No. 7

Pagos demorados de divlsas requerldas y autrlzadas (Millones de dólares y colones)

\begin{tabular}{|c|c|c|c|c|}
\hline \multirow[t]{2}{*}{ Dato semanal } & \multicolumn{2}{|c|}{ Pagos demorados } & \multirow{2}{*}{$\underset{c}{\operatorname{RIN}}$} & \multirow{2}{*}{$\underset{\leftarrow}{\text { RIN ajustadas }}$} \\
\hline & $\$$ & 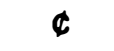 & & \\
\hline $12-27-85$ & 93.6 & 234.0 & (11.4) & (245.4) \\
\hline $01-03-86$ & 80.5 & 201.3 & 24.8 & (176.5) \\
\hline $01-10-86$ & 73.7 & 184.3 & $(4.6)$ & (188.9) \\
\hline $01-17-86$ & n.a. & n.a. & (20.2) & n.a. \\
\hline $01-24-86$ & n.a. & n.a. & (35.0) & n.a. \\
\hline $01-31-86$ & n.a. & n.a. & (47.3) & n.a. \\
\hline $02-07-86$ & 100.4 & 50.0 & (70.7) & $(572.7)$ \\
\hline $02-14-86$ & n.a. & n.a. & (65.1) & n.a. \\
\hline $02-21-86$ & n.a. & n.a. & (27.5) & n.a. \\
\hline $02-28-86$ & 108.1 & 270.3 & 649.5 & 3.79 .2 \\
\hline $03-07-86$ & 107.1 & 267.8 & 584.2 & 316.4 \\
\hline $03-14-86$ & 143.0 & 357.5 & 713.0 & 355.5 \\
\hline $03-21-86$ & 144.0 & 720.0 & 784.0 & 64.5 \\
\hline $03-28-86$ & 151.1 & 755.5 & 769.8 & 14.3 \\
\hline $04-04-86$ & 163.4 & 817.0 & 859.6 & 42.6 \\
\hline $04-11-86$ & n.a. & n.a. & 816.6 & n.a. \\
\hline $04-18-86$ & n.a. & n.a. & n.a. & n.a. \\
\hline
\end{tabular}

n.a. - no disponible

- RIN - Reservas internacionalos netas.

Fuente: Banco Central de Reserva de El Salvador, Departamento de Investigaciones Económicas. Memorandum No. 65/86.

de exportaciones, hecho ante los cuales muy poco o ningún control ejer cía el "Departamento de Control de Cambios".

En el cuadro 8 puede observarse que para 1985 las principales fuentes de financiamiento del mercado oficial fueron las exportaciones de bienes (59\% del total de divisas percibidas en este mercado), el capital bancario $(25 \%)$ y el rubro que agnupa servicios varios $(4.4 \%)$. Los principales egresos en el mercado oficial fueron en concepto de importaciones (48\%), capital bancario $(30 \%)$ y servicios por inversiones internacionales $(8 \%)$.

En el mercado paralelo en 1985 la mayor parte de divisas provino de las exportaciones de bienes $(59 \%)$ al segundo grupo en importancia era la cuenta servicios con $14 \%$ y luego la entrada de capital bancario 
Cuadro No. 8

Balanza de pagos de El Salvador por mercado camblarlo 1985*

(Miles de colones)

\begin{tabular}{|c|c|c|c|c|c|c|c|c|c|c|c|c|c|}
\hline \multirow[b]{3}{*}{ I. $\mathrm{E}$} & \multirow{4}{*}{$\begin{array}{l}\text { Blones, Serv. y Trand. } \\
\text { 1. Blone }\end{array}$} & \multicolumn{3}{|c|}{ Mercado Oficial } & \multicolumn{3}{|c|}{ Mercado paraleb } & \multicolumn{3}{|c|}{ Cuentas Especiales } & \multicolumn{3}{|c|}{ Dólares balanza } \\
\hline & & Ingrises & Egresos & Saboo & & & & & & & - & & \\
\hline & & $1,680,630$ & $1.474,004$ & 205,965 & 261.742 & 573,311 & $(311,509)$ & 30,956 & 27,571 & 3.385 & $1,973,567$ & 2.075 .786 & $(102,219)$ \\
\hline & & $1,300,343$ & $1,124,001$ & 265,352 & 178,940 & 499,760 & $(322,823)$ & 12,639 & 20,368 & $(7.727)$ & $1,579,822$ & $1,645,020$ & $(65,190)$ \\
\hline & a) Autera de C.A. & $1,213,390$ & 018.196 & 295,194 & 110.900 & 354,900 & $(244,007)$ & 11,830 & 18.762 & $(8,932)$ & 1.336 .122 & $1,291,867$ & 44.255 \\
\hline & b) Dentro od C.A. & 178,053 & 208,695 & (29.842) & 60,038 & 144,854 & $(78,818)$ & 600 & 1,604 & (795) & 243,700 & 353.153 & $(109.453)$ \\
\hline & 2. Treseporte & 9,321 & 35,462 & $(26.141)$ & 5.273 & 8,488 & $(12,215)$ & 170 & $\infty$ & 86 & 14.773 & 42,043 & (27.270) \\
\hline & 3.Vlayes Internee & 4200 & 40.041 & (41,841) & 2,278 & 8,217 & $(5,241)$ & 85 & 445 & (380) & 8.541 & 54,703 & $(48,162)$ \\
\hline & 4.Invere. Imemadon & 30,690 & 187,440 & $(153,750)$ & 5,303 & 20,775 & $(15.472)$ & 0 & 1,869 & $(1,869)$ & 38,993 & 2310,004 & $(171.091)$ \\
\hline & 5.Serv. Qubernaremers & 52,623 & 10,005 & 42,528 & 8,680 & 0 & 8,680 & 308 & 0 & 308 & 61,619 & 10,095 & 51,524 \\
\hline & 8.Seguros & 4.497 & 32.268 & $(27.71)$ & 2,87 & 12,462 & $(9.595)$ & 50 & 34 & 25 & 7.433 & 44,764 & $(37,331)$ \\
\hline & 7.Sonvide varbe & 103.785 & 30,443 & 70.342 & 41,644 & 24.989 & 16.655 & 17,243 & 4.645 & 12,598 & 162,672 & 63,077 & 99.595 \\
\hline & 8.Tranif. y Ooracbone & 66,950 & 4.405 & $£ 2.545$ & 15,885 & 169 & 15,718 & 330 & 40 & 293 & 83,168 & 4.614 & 78.554 \\
\hline & 9.0ver & 15.560 & 050 & 14.701 & 2.656 & 40 & 2,400 & 130 & 80 & so & 18,546 & 1,387 & 17.159 \\
\hline II. & Movimbernos de Capinal & 665.190 & 657,087 & $(191,897)$ & 37.071 & 1,300 & 36.638 & 0 & 14,253 & $(14.253)$ & 703.161 & 872,673 & (169.512) \\
\hline & a) Ceplad Pivado & 231 & 13.750 & (13.519) & 0 & $\$ 05$ & $\operatorname{sos}$ & 0 & 0 & 0 & 231 & 14.655 & $(14,424)$ \\
\hline & b) Cepled Olclal & 68,858 & 143.000 & $(75,141)$ & 0 & 0 & 0 & 0 & 8,386 & $(8.386)$ & 68,858 & 152,385 & $(83.527)$ \\
\hline & C) Caphal Bancorb & $5 e 6,101$ & 600,300 & $(103,239)$ & 37.071 & 428 & 37,543 & 0 & 5,867 & $(5,867)$ & 634,072 & 705,634 & $(71,562)$ \\
\hline & Tolal & $2,346,050$ & $2,301, \infty 91$ & 14,068 & 290.713 & 574.644 & $(274.031)$ & 30,956 & 41,824 & $(10,868)$ & $2,676,728$ & $2,948,459$ & (271.731) \\
\hline
\end{tabular}

- Preliminar

Fuente: Banco Central de Reserva de El Salvador, Departamento de Control de cambios. Sección de Estadistica. 
con $12 \%$. La venta de divisas en ese anc en este mercado financió principalmente a las importaciones de bienes $(87 \%$ del total de divisas vendidas).

En sintesis el $69 \%$ de las divisas para importaciones se adquidiría en el mercado oficial, en donde también se canalizaba el $90 \%$ de las divisas vendidas para el pago de servicios inversiones internacionales. Prácticamente toda divisa requerida en la salida de capital bancario se vendia en el mercado oficial.

El $89 \%$ por ciento de las divisas de exportación de bienes se pagaban al tipo de cambio oficial y un $94 \%$ de las entradas de capitla bancario también era canalizado a través de este mercado.

Los grandes ganadores de la multiplicidad de cambio: los importadores en contraste con los exportadores a los que se les pagaba a un precio bastante bajo la divisa que generaban.

En cuanto a los ingresos fiscales, se dice que un sistema de tipos de cambio mú.tiples puede generar beneficios fiscales a través de tasas diferenciadas para las importaciones y para las exportaciones. La tasa dual de cambio equivale a un impuesto a ciertas importaciones, mientras que la tasa oficial representa un impuesto para las exportaciones.

En el cuadro 8, si se analizara por separado el mercado oficial, aparentemente habria una ganancia en la compra-venta de divisas por cuanto se recibieron $₫ 2346$ millones de divisas a $₫ 2.50$ por dólar, contra una venta de sólo $₫ 2332$ millones, lo que equivale a un superávit en el mercado oficial de $\$ 14$ millones pagados al precio más bajo.

Una ganancia de $₫ 35$ millones [ = 14 millones $X$ (5-2.50)]

Consecuencia de que la mayorla de ingresos de exportación estaban consignados al mercado oficial.

Sin embargo, al analizar el mercado paralelo vernos que este superávit de 14 millones no logró financiar los $\$ 275$ millones de dédicit en este mercado donde se vendieron $₫ 575$ millones contra $₫ 300$ millones. Podria haber sido una ventaja tener un déficit en el mercado paralelo en el sentido de que más fondos fueron vendidos que comprados a la tasa institucional más alta, pero si las divisas necesarias para solventar el déficit provinieron de capital compensatorio, deuda externa o de las reservas internacionales, y a esto anadimos que la tasa de cambio paralela esta sobrevaluada, este déficit en el mercado paralelo equivale a un deterioro de las condiciones del sector externo.

Además con la devaluación, los préstamos cuyas divisas hablan 
Cuadro No. 9

El tlpo de camblo de la parldad del poder de compra

1978-1985 $(1977=100)$

\begin{tabular}{lrrrrrrrr}
\hline & 1978 & 1979 & 1980 & 1981 & 1982 & 1983 & 1984 & 1985 \\
\hline Tipo de cambio oficial & 2.5 & 2.5 & 2.5 & 2.5 & 2.5 & 2.5 & 2.5 & 2.5 \\
PPP tipo de cambio* & 2.6 & 2.7 & 2.8 & 2.9 & 3.1 & 3.4 & 3.6 & 4.2 \\
Sobrevaluación (\%) & 5.1 & 8.3 & 12 & 15.6 & 22.7 & 34.6 & 44.0 & 70.1 \\
& & & & & & & & \\
\hline
\end{tabular}

- PPP - Paridad del poder de compra.

Cuadro No. 10

Diferencla entre los tipos de camblo en el mercado oficlal, paralelo y negro

\begin{tabular}{lrrrrrrrr}
\hline & 1978 & 1979 & 1980 & 1981 & 1982 & 1983 & 1984 & 1985 \\
\hline TCMN-TCMO (\%) & 21.8 & 32.2 & 90.8 & 105.4 & 94.7 & 117.8 & 132.0 & 135.2 \\
TCMN-TCMP (\%) & & & & & 26.1 & 37.7 & 31.2 & 33.3 \\
TCMN-TCPR (\%) & & & & & 79.8 & 97.0 & 60.0 & 39.0 \\
\hline
\end{tabular}

- TCMN - Tipo de cambio en el mercado negro, TCMO - Tipo de cambio en el mercado oficial, TCMP - Tipo de cambio on el mercado paralelo, TCPR Tipo de cambio promedio en el mercado oficial y paralelo.

Fuente: En base a datos del Depto. de Investigaciones Econ. B.C.R.

\author{
Cuadro No. 11 \\ Varlaciones en el PNB (\%) \\ 1962 Precios
}

\begin{tabular}{lrrrrrrrr}
\hline & 1978 & 1979 & 1980 & 1981 & 1982 & 1983 & 1984 & 1985 \\
\hline Caf́́ & 10.5 & 17.1 & -.8 & -6.6 & -.8 & -10.6 & -6.5 & n.a. \\
Algodón & 12.5 & -17.6 & -4.3 & -29.8 & -8.1 & 1.7 & -22.8 & n.a. \\
Cah́a de azúcar & 4.2 & -7.6 & -22.8 & -11.7 & 4.8 & 27.1 & 12.8 & n.a. \\
Bienes alimenticios basic. & 30.9 & 4.1 & -2.8 & -5.9 & -15.8 & 7.8 & 20.8 & n.a. \\
Construcción & -6.4 & -2.1 & -22.6 & -15.3 & -4.2 & 2.0 & -5.7 & 12.0 \\
Manufacturas & 4.5 & 5.0 & -10.8 & -10.4 & -8.4 & 2.0 & 1.3 & 4.5 \\
Comercio y servicios & & & & & & & & \\
personales & 5.7 & -7.1 & -25.4 & -23.5 & -17.6 & .3 .3 & 3.8 & n.a. \\
\hline
\end{tabular}

n.a. - No disponible

Fuente: Banoo Central de Reserva de El Salvador, Revista Menual, varios números. 
sido compradas al tipo de cambio oficial tuvieron que pagarse a un tipo de cambio mucho más alto.

Efecto de la sobrevaluación del tlpo de camblo especlalmente sobre los blenes de exportaclón

A pesar de las limitaciones existentes al computar la paridad del poder de compra del tipo de cambio hay algunas maneras de estimar la sobrevaluación del tipo de cambio oficial. En el cuadro 9 podemos estimar la sobrevaluación cuando se compara con el tipo de cambio necesario para mantener el poder de compra necesario usando 1977 como ano base.

Aunque los tipos de cambio en el mercado negro no constituyen el tipo de cambio de equilibrio, la desviación del tipo de cambio con el mercado paralelo puede usarse como un Indice para medir la sobrevaluación de la tasa de cambio. Entre más sobrevaluado este el tipo de cambio más grande será el exceso de demanda de dólares, y a su vez este exceso presionarla por un aumento en el precio de la divisa en el mercado negro. Las diferencias entre el tipo de cambio en el mercado oficial, paralelo y negro se muestran en el cuadro 10.

Los efectos de la sobrevaluación del tipo de cambio sobre los patrones de consumo y reasignación de recursos en El Salvador no es tan claro porque simultáneamente a este fenómeno hubo una contracción en la economía debido a factores tanto económicos como no económicos y a causas estructurales y coyunturales. Esta contracción en la economla lleva a una reducción aún mayor en las exportaciones, ya de por si disminuidas con el tipo de cambio sobrevaluado. De la misma manera las importaciones, que dependen grandemente del nivel del producto nacional, cayeron a pesar de la sobrevaluación del cambio. La producción de bienes no comerciables decreció con el desaceleramiento de la economia.

Al mismo tiempo los controles sobre las transacciones de moneda extranjera ayudaron a disminuir las importaciones. Sin embargo, la creciente acumulación de pagos demorados es una senal clara que la demanda de dólares no estaba siendo satisfecha en el mercado paralelo. La oferta de dólares era insuficiente aún cuando grandes donaciones y IIneas especiales de crédito se obtuvieron sobretodo de los Estados Unidos.

En 1980, el tipo de cambio en el mercado negro estaba $90.8 \%$ arriba del cambio oficial (ver cuadro 10) mientras que el ano anterior habla estado solamente un $32.2 \%$. Este ano las importaciones decrecieron más que las exportaciones en términos reales sobretodo por la 
disminución por primera vez de 1979 a 1980 del PNB y por la introducción de una serie de controles cambiarios. Debe considerarse que si bien se puede hablar de una fuerte sobrevaluación del colón en este ano, la disminución de las exportaciones que esto genera puede no haberse manifestado a plenitud este ano dado al carácter rigido a corto plazo de la oferta de los productos agricolas que constituyen el grueso de nuestras exportaciones.

En 1981, el precio del dólar en el mercado negro estaba un $105.37 \%$ sobre el tipo de cambio oficial y la cuenta comercial de la balanza de pagos mostraba un déficit tanto en términos nominales como reales. Los cambios estructurales de 1980 y el tipo de cambio sobrevaluado afectaron sobretodo a los principales productos de exportación.

En 1982, cuando el mercado paralelo comienza a funcionar, el tipo de cambio del mercado ilegal se encontraba un $26.4 \%$ y un $94.74 \%$ sobre la tasa de cambio en el mercado paralelo y en el oficial respectivamente y la cuenta comercial siempre registró un déficit. La politica de austeridad y controles selectivos sobre las importaciones que continuaron a través del ano, y la contracción del PNB contribuyeron a que este déficit no se acentuara.

En 1983, el PNB empezó a elevarse cuando el crédito doméstico se dirigió hacia el sector privado. Tanto las importaciones como las exportaciones aumentaron, y la cuenta comercial presentó un déficit de $\$ 390.4$ millones. Este ano el mejoramiento en las exportaciones se debió sobretodo a las exportaciones no tradicionales que gozaron de un trato preferencial en el mercado paralelo y que habian sido promovidas en años anteriores por las autoridades. Los bienes de capital e intermedios aumentan como resultado de reponerse inventario o debido a la sobrefacturación, los bienes de consumo mostraron un ligero incremento favorecido por algunas medidas de liberación. El déficit en la cuenta comercial continuó en 1984 y 1985. En general, las exportaciones a palses fuera del área centroamericana respondieron positivamente a los incentivos otorgados por las autoridades en el mercado paralelo. Sin embargo, las exportaciones no tradicionales a Centro América se deterioraron debido a los conflictos en la región. Las exportaciones de bienes tradicionales támbién disminuyeron siendo una de las causas el tipo de cambio sobrevaluado.

El efecto de esta sobrevaluación se mira más claramente cuando se examina la producción de los principales productos de café, algodón y azúcar. Estos productos permanecieron en el mercado oficial y las divisas que generaron fueron vendidas a un tipo de cambio cada vez más sobrevaluado. 
En el cuadro 11 se mira como la producción de caté, algodón y caha de azúcar empezó a declinar entre 1979 y 1980, periodo cuando la reforma agraria y la nacionalización de la banca tuvo lugar.

El café y el algodón disminuyeron consistentemente, desde esa época con la excepción de 1983 cuando el algodón aumentó un 1.7\%. Sólo la producción del azúcar presenta una tendencia distinta pues su producción empieza a aumentar en 1982.

Detrás de esta expansión estuvieron las concesiones otorgadas al pals por los Estados Unidos de parte de la cuota suspendida a Nicaragua, y la rehabilitación de una plantación de azúcar.

Los sectores que presentaron la mayor recuperación en anos recientes fueron el sector manufacturero, el sector construcción y el sector servicios. Estos sectores pueden considerarse como productores de bienes no comerciables o como sectores altamente dependientes de insumos importados. El sector construcción fue especialmente estimulado con las líneas especiales de crédito que fueron reabientas para las firmas constructoras y para familias de mediano y alto ingreso.

Otro aspecto del mercado paralelo es su influencia sobre los precios. En 1982, cuando el mercado paralelo se crea y se vuelven a autorizar divisas para algunas operaciones que antes habian sido suspendidas, el tipo de cambio del mercado negro disminuyó aproximadamente $5 \%$. Como esta tasa de cambio también influye en las expectativas de la gente, su reducción contribuyó a la baja en la tasa de inflación en 1982.

Aunque la inflación continuó durante 1983 y 1984, no hubieron agudos incrementos en la tasa de inflación. La tasa de crecmiento del producto nacional bruto ayudó a contener la inflación al resolver problemas de sobre demanda.

Sin embargo, cuando la mayorla de importaciones esenciales se transfirieron del mercado oficial al mercado paraleb en 1985, la tasa de inflación se duplico.

Un modelo econométrlco para medir el efecto de varlaclones en el tlpo de camblo sobre las Importaclones, exportaclones y sobre el nlvel de preclos

Estamos interesados en medir los efectos de las variaciones del tipo de cambio en el mercado paralelo y en el mercado negro sobre el comercio externo y sobre el proceso inflacionario del pais.

Cuatro equaciones han sido formuladas. Las primeras dos son las 
funciones de demanda de importaciones y oferta de exportaciones para El Salvador. La tercera ecuación mide la contribución de las variaciones en el tipo de cambio sobre el nivel de precios doméstico. La cuarta ecuación pretende captar como se determina el precio del dólar en el mercado negrn. Aunque el tipo de cambio oficial y paralelo fueron tasas controladas, debido a la presencia de un mercado negro modelamos una economia con tipo de cambio flexible.

Tratamos de incorporar la relación entre el mercado de exportación y el de Importación. Un pals utiliza sus ingresos de divisas de las exportaciones para financiar sus importaciones, haciendo estas últimas depender de las primeras.

Esta relación se considera que es una relación causa-efecto unidireccional y rezagada.

Ya hemos mencionado que aumentos en el tipo de cambio conducen a presiones inflacionarias. La depreciación de la moneda aumentará el nivel de precios domésticos de las importaciones y exportaciones y el precio de los bienes para cuya producción se utilizan bienes intermedios 0 insumnos importados.

Cambios de demanda de los bienes comerciables a los no comer-

Cuadro No. 12

\section{Modelo de ecuaclones}

1) $L X_{1}=$

$a_{1}+a_{2} L X_{1-1}+a_{3} L P x e / P_{1}+a_{4} L P X e / P_{T-1}+A_{5} L P X / P_{T}+$ $a_{8} L P X / P_{1-1}+a_{7} L C R_{1}+a_{8} D 1_{1}+a_{8} D 2_{1}+a_{10} L T_{1}$

2) $L M_{1}=$

$b_{1}+b_{2} L P m e / P_{1}+b_{3} L P m / P_{1}+b_{4} N F A_{-1}+b_{5} L D X_{L_{1}}$ $+b_{8} L M_{t-1}+b_{7} L G D P_{1}+b_{8} L M S R_{1}+b_{9} D 1_{1}+b_{10} D 2_{1}+$ $b_{11} L T_{1}$

3) $L P_{1}=B_{1}+B_{2} E_{1}+B_{3} E_{1-1}+B_{4} L M S_{1}+B_{5} L M S_{1-1}+B_{8} L G D P_{1}+$ $B_{7} L G D P_{1-1}+B_{8} P_{1-1}+B_{0} P_{1-2}+B_{10} L P m_{1}+B_{11} D 1_{1}+$ $B_{12} D 2_{1}+B_{13} L T_{1}$

4) $E_{1}=C_{1}+C_{2} L M S_{1}+C_{3} L_{M S}+C_{1-1} N F A_{1}+C_{5} L_{G D P_{1}}+C_{8} L_{G D P_{1-1}}$ $+C_{7} L E_{t-1}+C_{8} L E_{1-2}+C_{9} L P_{1}+C_{10} L P_{1-1}+C_{11} D_{1}+C_{12} D 2_{1}+$ $\mathrm{C}_{13} \mathrm{LT}$, 


\section{Varlables ondógonas}

$$
\begin{aligned}
X \quad= & \text { Exportaciones en términos } \\
& \text { reales. } \\
M \quad= & \text { Importaciones en términos } \\
& \text { reales. } \\
P \quad= & \text { Nivel de precios domésticos. } \\
& \\
E \quad= & \text { Tipo de cambio nominal en } \\
& \text { el mercado negro. }
\end{aligned}
$$

PX/P = Precio relativo de las exportaciones con respecto al indice de precios domésticos convertido en colones usando el tipo de cambio oficial.

$\mathrm{Pm} / \mathrm{P}=$ = Precio relativo de las importaciones respecto al indice de precios doméstico convertido a colones utilizando el tipo de cambio oficial.

Pme/P = Precio relativo de las importaciones con respecto al indice de precios domésticos convertido a colones usando el tipo de cambio en el mercado negro.

GDP = Producto nacional bruto on términos reales.

DX = Ingresos de exportaciones deflatadas usando el Indice de precios a la importación.

MSR = Oferta de saldos reales.

\section{Variables exógenas}

MS = Oferta nominal de dinero.

CR = Crédito doméstico al sector privado en términos reales.

Px - Indice de precios de las exportaciones convertido a colones usando el tipo de cambio oficial.

Pxe = Indice de precios de exportación convertido a colones usando el tipo de cambio on el mercado negro.

$\mathrm{Pm}$ = Indice de precios a la importación convertido a colones utilizando el tipo de cambio oficial.

Pme = Indice de precio a las importaciones utilizando el tipo de cambio en el mercado negro.

NFA = Activos extranjeros netos del sistema bancario consolidado deflatado por el indice de precios a las importaciones.

D1 - Variable ficticia para los años de conflicto 1978-1984.

D2 = Vairable ficticia para los años de existencia del mercado paralelo 1982-1984

$T=$ Variable que capta la tendencia en el tiempo.

El subíndice $T$ indica el período de tiempo

La letra L significa logaritmo

Las variables rezagadas tanto endógenas como exógenas se consideran como variables predeterminadas. 
ciables también hará aumentar el precio de los bienes no comerciables. La gente comenzará a demandar mayores salarios para mantener su poder de compra.

\section{El modelo}

El modelo se desarrolla para un pais pequeno, tomador de precios. El modelo es simple en el sentido que solo se han considerado algunas variables explicatorias y algunas relaciones. Las relaciones son lineales tanto en las variables como en los parámetros. Por simplificación y para mantener los grados de libertad dado los datos limitados con que se cuenta, sólo se han considerado rezagos de uno o dos anos.

El modelo incluye cuatro ecuaciones de comportamiento. La forma econométrica del modelo se muestra en el cuadro 12.

Ecuación de exportaclones

$$
\begin{aligned}
L X_{1}= & a_{1}+a_{2} L X_{1-1}+a_{3} L P x e / P_{1}+a_{4} L P x e / P_{1-1}+ \\
& a_{5} L P x / P_{1}+a_{6} L P x / P_{1-1}+a_{7} L C R_{1}+a_{8} D 1_{1}+ \\
& a_{0} D 2_{1}+a_{10} L T_{1}
\end{aligned}
$$

La oferta de exportaciones en términos reales $(X)$ se asume que depende de:

i) El valor de las exportaciones del periodo anterior $\left(X_{L_{-}}\right)$.

ii) Los precios relativos de las exportaciones de este periodo y del perlodo anterior, convertidos a colones usando la tasa de cambio del mercado negro (Pxe/P).

iii) Los precios relativos de las exportaciones de este perlodo y del perlodo anterior, convertidos a colones usando la tasa de cambio del mercado oficial (Px/P).

iv) El crédito para el sector privado en términos reales (CR).

iv) La situación en el pals durante 1978-1984 (D1).

ivi) El comportamiento de la tasa de cambio en el mercado paralelo durante 1982-1984 (D2).

ivii) La tendencia en el tiempo (T).

Todas estas variables se han expresado en logaritmo.

El crédito para el sector privado se espera que sea una variable importante debido que continuamente los productores de café aduclan 
la falta de financiamiento para la producción como uno de los principales motivos de la baja en la cosecha de café.

De la misma manera, gran parte de la reducción en las áreas cultivadas se debió a los actos de sabotaje contra los sembrados, efecto que se pretende captar a través de la variable ficticia D1. La sobrevaluación del tipo de cambio en el mercado paralelo desincentivó la producción de bienes de exportación. Este efecto se puede medir a través del precio relativo de las exportaciones convertido a colones usando el tipo de cambio del mercado negro. Entre mayor sea el precio de la divisa en el mercado negro, mayor será la diferencia del precio del dólar en el mercado negro y en el mercado oficial. La sobrevaluación puede asimismo ser medida a través de la variable ficticia D2 que captura las variaciones del tipo de cambio en el mercado paralelo sobre el valor de las exportaciones. Esta variable indicará si los exportadores tomaban sus decisiones más en base al comportamiento del precio de la divisa en el mercado negro que en el mercado oficial. Como la mayor proporción de los bienes exportados son productos primarios cuya producción no puede responder en forma inmediata a cambios en los precios, se ha incluido el precio relativo de las exportaciones para periodos pasados.

\section{Ecuación de la demanda de Importaclones}

El logaritmo de a demanda de importaciones en términos reales se especifica como sigue:

$$
\begin{aligned}
\mathrm{LM}_{1}^{d}= & Z_{1}+Z_{2} \mathrm{LPme} / \mathrm{P}_{1}+Z_{3} \mathrm{LPm} \mathrm{P}_{1}+\mathrm{Z}_{4} \mathrm{NFA}_{-1}+ \\
& \mathrm{Z}_{5} \mathrm{LDX}_{-1}+\mathrm{Z}_{6} \mathrm{LGDP}_{1}+\mathrm{Z}_{7} \mathrm{LMSR}_{1}+ \\
& \mathrm{Z}_{8} \mathrm{D} 1_{1}+\mathrm{Z}_{0} \mathrm{D} 2_{1}+\mathrm{Z}_{10} \mathrm{LT} \mathrm{T}_{1}
\end{aligned}
$$

El logaritmo de la demanda de importaciones en términos reales (Md) se asume función de:

i) El logaritmo del precio relativo de las importaciones convertido en colones usando el tipo de cambio del mercado negro (Pme/P).

ii) El logaritmo del precio relativo de las importaciones convertido a colones usando el tipo de cambio oficial (Pm/P).

iii) Los activos extranjeros netos del perlodo anterior del sistema bancario, deflatados utilizando el indice de precio de las importaciones (NFA).

iv) El logaritmo del valor de las exportaciones del perlodo anterior deflatado con el índice de precios de las importaciones (DX). 
v) La situación política del país medida a través de una variable ficticia (D1).

vi) El desempeno del mercado paralelo (D2).

vii) La tendencia en el tiempo (T).

Se asume que hay un ajuste parcial en el tiempo en la demanda de importaciones. Asi la diferencia entre el valor de las importaciones de este ano y el valor del ano pasado es una fracción de la diferencia entre el valor de la demanda de importaciones en este ano y las importaciones del ano anterior.

$$
L M_{1}-L M_{1-1}=\gamma\left(L M_{1}^{d}-L M_{t-1}\right)
$$

Donde $d$ significa demanda, $t$ indica el periodo, $M$ son las importaciones en términos reales y $\gamma$ es el coeficiente de ajuste.

Md es la demanda de importación deseada en el periodo t. Sin embargo, hay costos involucrados en el ajuste de las importaciones a un nivel deseado, y sólo se logra un ajuste parcial dentro del período.

Sustituyendo la ecuación 1 en la ecuación 2, y luego resolviendo para el logaritmo de las importaciones del periodo presente $\left(L_{1}\right)$, obtenemos la segunda ecuación del modelo. En esta ecuación el logaritmo de las importaciones presentes en términos reales es, entre otras cosas, función del logaritmo de las importaciones en términos reales del periodo anterior.

$$
\begin{aligned}
\mathrm{LM}_{1}= & \gamma \mathrm{Z}_{1}+\gamma \mathrm{Z}_{2} \mathrm{LPme}_{\mathrm{P}}+\gamma \mathrm{P}_{1} \mathrm{LPm}_{1} \mathrm{P}_{1}+\gamma \mathrm{Z}_{4} \mathrm{NFA_{1-1 }}+ \\
& \gamma \mathrm{Z}_{8} \mathrm{LDX}_{1-1}+\gamma \mathrm{Z}_{8} \mathrm{LM}_{1-1}+\gamma \mathrm{Z}_{1} \mathrm{LGDP}+ \\
& \gamma \mathrm{Z}_{8} \mathrm{LMSR}_{1}+\gamma \mathrm{Z}_{8} \mathrm{D} 1_{1}+\gamma \mathrm{Z}_{10} \mathrm{D2} 2_{1}+\gamma Z_{11} \mathrm{LT}_{1}
\end{aligned}
$$

Esta ecuación de desequilibrio (la demanda de importaciones no coincide con la oferta de importaciones) puede reescribirse asi:

$$
\begin{aligned}
L M_{1}= & b_{1}+b_{2} L P m e / P_{1}+b_{3} L P m / P_{1}+b_{4} N F A_{L-1}+b_{5} L D X_{1-1}+ \\
& b_{0} L M_{1-1}+b_{7} L G D P_{1}+b_{6} L M S R_{1}+ \\
& b_{0} D 1_{1}+b_{10} D 2_{1}+b_{11} L T_{1}
\end{aligned}
$$

Los activos netos extranjeros del sistema bancario deflatados con el indice de precios de las importaciones se ha tomado con un indice del control de las importaciones en el supuesto que dependiendo del nivel que alcancen los activos extranjeros netos las autoridades endurece- 
rian o suavizarian las restricciones a las divisas. Aunque el producto doméstico bruto sería más preciso de usar (recuérdese que la mayoría de bienes de importación en el país lo constituyen materias primas y bienes intermedios usados en la producción manufacturera), la falta de información respecto a esta variable nos obligó a utilizar el PNB a términos constantes. Se asume que el aumento en la oferta de saldos reales llevará a un aumento en la adquisición de bienes de consumo importados. La variable Dx refleja la habilidad de la gente para usar divisas para comprar bienes de consumo extranjero. De nuevo, se asume que la situación política ha influenciado las importaciones debido a que muchas fábricas han cerrado o disminuido su producción.

Como en la ecuación de exportaciones, el precio relativo de las importaciones convertido en colones usando el tipo de cambio en el mercado negro, y la variable dummy D2 indicarán la efectividad del mercado paralelo en el comportamiento de las exportaciones. Si el tipo de cambio dual esta sobrevaluado, se espera un aumento en las importaciones si la diferencia entre esta tasa de cambio y la prevaleciente en el mercado negro aumenta.

\section{Ecuaclón de preclos domésticos}

$$
\begin{aligned}
P_{1}= & B_{1}+B_{2} L E_{1}+B_{3} L E_{1-1}+B_{1} L M S_{1}+B_{6} L M S_{1-1}+ \\
& B_{6} L G D P_{1}+B_{7} L G D P_{1-1}+B_{6} L P_{1-1}+B_{6} L P_{12}+ \\
& B_{10} L P_{1}+B_{11} D 1_{1}+B_{12} D 2_{1}+B_{13} L T_{1}
\end{aligned}
$$

El logaritmo del nlvel de preclos doméstloos (P) se considera afectado por:

i) El logaritmo del tipo de cambio en el mercado negro (E) de este perlodo y del perlodo pasado.

ii) El logaritmo de la oferta monetaria nominal (MS) del presente período y del pasado.

iii) El logaritmo del PNB a precios constantes (GDP) del presente período y del pasado.

iv) El Indice de precios al consumidor $(P)$ rezagado uno y dos periodos.

iv)El logaritmo del indice de precios de las importaciones (Pm).

vi) La situación política (D1).

vii) Las variaciones del tipo de cambio en el mercado paralelo (D2). 
viii) El logaritmo de la variable tiempo.

La ecuación de precios puede pensarse como una curva de demanda de dinero invertida. Se asume que los precios no cambian to suficlentemente rápido como para adecuar la demanda de dinero a la oferta dentro del mismo perlodo por la cual se introduce la oferta monetaria del período anterior. La tasa de inflación actual también se verá influenciada por la tasa esperada de inflación (via demanda de dinero). A su vez, la tasa esperada de inflación se asume que depende de la tasa de inflación de perlodos anteriores, del precio de las importaciones de las tasas de cambio. Estas variables afectarán el nivel de precios domésticos a través de las expectativas de inflación que se forma la gente. Cambios en el Ingreso real también afectará los precios al alterar la demanda de dinero.

Ecuación del tipo de camblo en el mercado negro

El logaritmo del precio del dólar en el mercado negro se específica de la siguiente manera:

$$
\begin{aligned}
L E_{1}= & C_{1}+C_{2} L M S_{1}+C_{3} L M S_{1-1}+C_{4} M F A_{1}+ \\
& C_{6} L G D P_{1}+C_{6} L E_{1-1}+C_{7} L E_{T-2}+C_{8} L P_{1}+ \\
& C_{0} L P_{1-1}+C_{10} D 1_{1}+C_{11} D 2_{1}+C_{12} L T_{1}
\end{aligned}
$$

El logaritmo del tipo de cambio (E) en el mercado negro se asume ser función de:

i) El logaritmo de la oferta monetaria nominal del período presente y pasado (MS).

i) El nivel de activos extranjeros netos en el sistema bancario deflatado por el índice de precios de las importaciones (NFA).

lii) El logaritmo del PNB a precios constantes de este período y del pasado (GDP).

Iv) El logaritmo del tipo de cambio en el mercado negro (E) rezagado uno y dos perlodos.

v) Del indice de precios al consumidor $(P)$ con uno y dos perlodos de rezago.

ivi) Las variables ficticias D1 y D2, representando el conflicto político y el funcionamiento del mercado paralelo respectivamente.

vii) El logaritmo de la variable tiempo (T). 
El tipo de cambio en el mercado negro se asume que se determina simultáneamente por la demanda y oferta de divisas. El logaritmo de la demanda de dólares en el mercado negro (D\$) se asume que depende del logaritmo de la oferta monetaria (MS) del periodo presente y pasado, de el logaritmo del tipo de cambio en el mercado negro (E), del logaritmo del producto nacional bruto en términos reales (GDP), y del logaritmo del valor esperado del precio del dólar en el mercado negro en el siguiente perlodo $\left(E\left[E_{1}, 1\right)\right.$ :

$$
\begin{aligned}
& L D_{1}^{s}=y_{1}+y_{2} L M S_{1}+y_{3} L M S_{t-1}+y_{4} L E_{T}+ \\
& \left.y_{6} \text { LGDP }_{1}+y_{0} \text { LEX[E }+1\right]
\end{aligned}
$$

El logaritmo del valor esperado del tipo de cambio futuro incluye el logaritmo del Indice de precios de este período y del pasado, el logaritmo del tipo de cambio en el mercado negro del perlodo y rezagado uno y dos perlodos:

$$
\begin{aligned}
\operatorname{LEX}\left[E_{t+1}\right]= & f_{0}+f_{1} L P_{1}+f_{2} L P_{1-1}+f_{3} L E_{1}+ \\
& f_{4} L E_{t-1}+f_{6} L E_{1-2}
\end{aligned}
$$

Entre más dinero haya en la economla la gente querrá transformar parte de este dinero en divisas para prevenir la posible pérdida del poder adquisitlvo del colón. De la misma manera, si hay expectativa de precios más altos para el dólar, la gente comprará ahora esperando ganar en el futuro.

El logaritmo de la oferta de dólares en el mercado negro (Ss) se asume que depende de el logaritmo del precio del dólar ahora y de los activos extranjeros netos. Esta última varlable se ha Incluido como indicador de la fuga de divisas desde el mercado oflclal hacia el mercado negro:

$$
L^{*}=\gamma_{0}+\gamma_{1} L E_{1}+\gamma_{2} N F A
$$

Despejando el logaritmo tipo de cambio en el mercado negro (E) de las ecuaciones de la oferta y demanda de divisas, obtenemos la cuarta ecuación que aparece en nuestro modelo. De nuevo las variables D1, D2 y $T$ representan los conflictos políticos, el mercado paralelo y la tendencia en el tiempo.

Nótese que no tenemos un modelo completo porque no tenemos ecuaciones para el consumo e inversión agregada, y esto ha sido más 
que nada por falta de datos.

Las ecuaciones estructurales cumplen con las condiciones de orden para identificación.

\section{Resultados}

El modelo fue estimado utilizando 27 observaciones anuales para el perlodo 1958-1994.

Las ecuaciones se estimaron usando minimos cuadrados en dos etapas y minimos cuadrados en tres etapas, para poder capturar el efecto de determinación simultánea de las variables endógenas. También se usó el método de maxima verocimilitud.

Cuadro No. 12

\section{Parametros estructurales estimados}

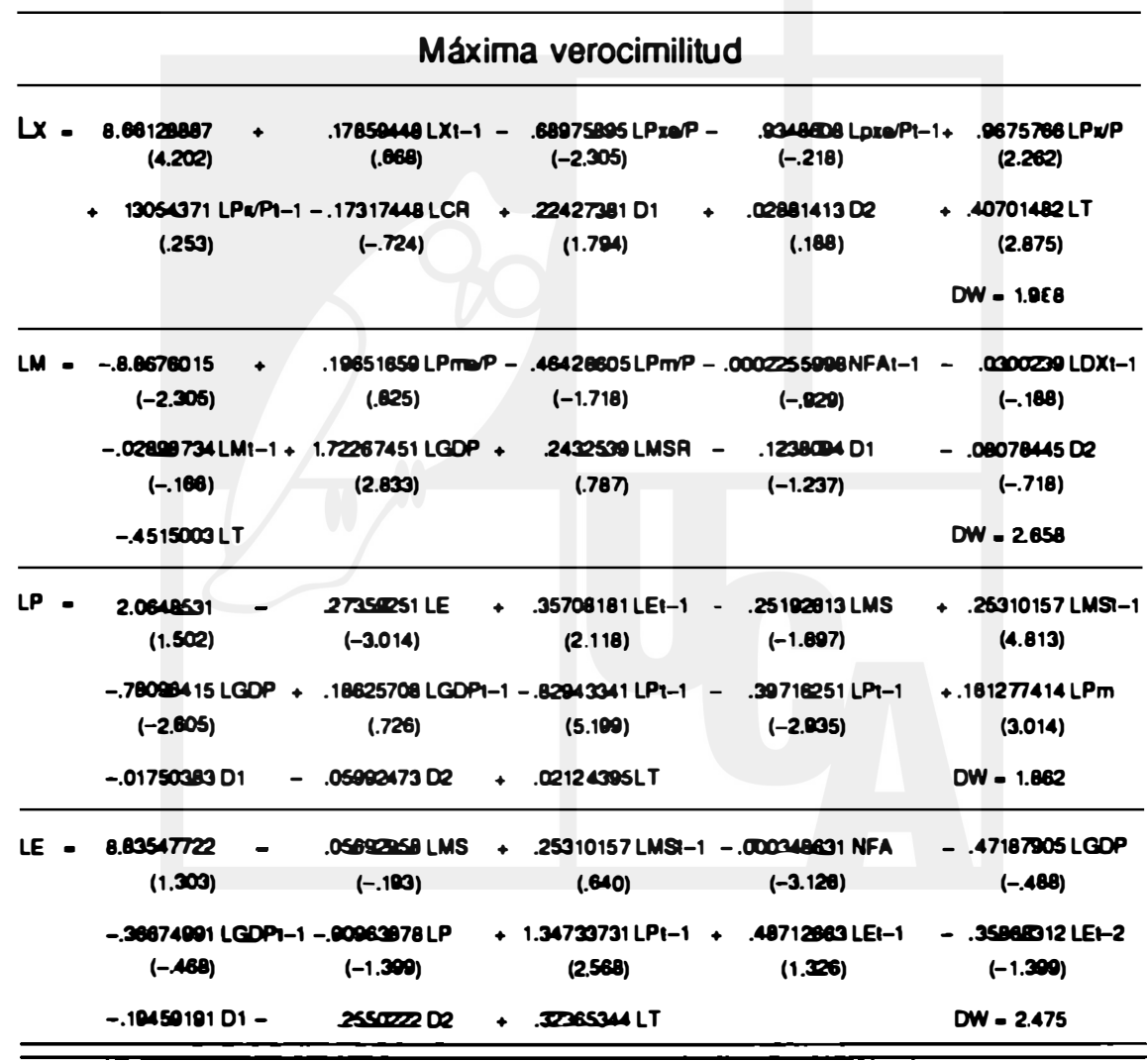

Valores t entre paréntesis 
La mayoria de coeficientes aumentaron sus valores bajo este último método por lo que solo presentaremos y analizaremos los resultados asi obtenidos (ver cuadro No. 12).

El sistema como un todo presenta una $R$ cuadrada ponderada de .999532, con un error cuadrado de .941858 .

En la ecuación de las exportaciones solo los coeficientes estimados para el precio relativo de las exportaciones en el periodo presente, tanto convertidos con la tasa de cambio oficial y la del mercado negro, y la variable tiempo fueron significativos a un nivel del $5 \%$. La variable ficticia D1 es significativa para un nivel del $10 \%$. De acuerdo a los resultados un incremento del $1 \%$ en el precio relativo de las exportaciones (convertida usando la tasa de cambio oficial) lleva a un $0.97 \%$ aumento en el las exportaciones, mientras que el aumento de $1 \%$ de esta misma variable pero convertida a colones utilizando el precio del dólar en el mercado negro genera una disminución del .69\% en las exportaciones.

Esto provee evidencia de que la producción de los principales productos de exportación se vieron afectados por la existencia de un tipo de cambio sobrevaluado al cual los exportadores tenian que vender las divisas de ingresos por exportación.

En la ecuación estimada para las importaciones se evidencia claramente su asombrosa dependencia con el nivel del producto nacional bruto.

El coeficiente para esta variable implica que un aumento del $1 \%$ en el PNB aumenta las importaciones en $1.72 \%$.

Como se esperaba se obtuvo una baja elasticidad para los precios relativos $(-.46 \%)$.

Ninguno de los otros coeficientes fueron estadisticamente significativos con la excepción de la variable tiempo que presenta un coeficiente de .45 .

La ecuación de los precios muestra que los coeficientes oe el producto nacional bruto del período pasado, el conflicto bélico, el mercado paralelo y la variable tiempo no fueron significativamente diferentes de cero para un nivel de confianza del $90 \%$.

El coeficiente de la oferta monetaria no tuvo el signo esperado ya que indicaba que un aumento del $1 \%$ de la oferta de saldos reales produce una baja en los precios del $.25 \%$. Sin embargo, este coeficiente presenta un alto valor de error estandar por to que no podemos rechazar la hipótesis de que su verdadero valor es cero. El coeficiente de la 
oferta monetaria rezagada un periodo revela que un aumento del $1 \%$ de la cantidad nominal de dinero incrementa un $.23 \%$ los precios. Esto puede ser indicio de que el ajuste de saldos reales no se lleva a cabo en el mismo periodo sino que toma cierto tiempo.

Los precios parecen responder más al producto nacional bruto, ya que un aumento del $1 \%$ en esta variable me produce una disminución del $.78 \%$ en los precios.

Las expectativas de inflación parecen ser los determinantes más importantes en el nivel de precios puesto que el coeficiente de el indice de precios al consumidor rezagado uno y dos periodos son 0.83 y -0.40 respectivamente. De igual manera un aumento del $1 \%$ en la tasa de cambio en el mercado negro produciría una caida del $.27 \%$ en los precios. Sin embargo, un aumento del $1 \%$ de esta misma variable rezagada un periodo tiene un ef ecto positivo del $0.38 \%$.

El nivel de precios domésticos también estaba influenciado por el precio de las importaciones aunque en menor cantidad.

Finalmente, los coeficientes estimados para la ecuación del tipo de cambio en el mercado negro que son estadísticamente significativos a un nivel del $10 \%$, son los activos extranjeros netos y el nivel de precios de periodos anteriores. Esta última variable tiene una gran influencia ya que un aumento del $1 \%$ genera un aumento del $1.35 \%$ en el precio del dólar. Este resultado provee evidencia de que la especulación es un componente importante en la determinación del precio del dólar en el mercado negro. No parece haber indicaciones de que el mercado paralelo haya contribuido a bajar el precio de la divisa en el mercado ilegal.

Al interpretar todos estos resultados debemos tomar en cuenta que muchos elementos, especialmente factores socio-políticos no se han podido incluir o cuantificar adecuadamente. Es más, en la década de los ochenta el comportamiento de la economia cambió radicalmente y hay que recordar que estos coeficientes se han estimado utilizando una serie de anos bastante grande pero que por lo mismo no logran mostrar a plenitud el comportamiento particular de la economia en anos recientes.

\section{Conclusiones}

El proceso inflacionario, la falta de confianza de la gente en el sistema, y un tipo de cambio que las autoridades monetarias habian mantenido fijo por mucho tiempo dieron como resultado un tipo de cambio cada vez más sobrevaluado. 
La sobrevaluación significó un costo para los exportadores, al mismo tiempo que incentivó las importaciones.

El déficit comercial se hizo cada vez mayor y esta situación se vio reflejada en la pérdida de reservas internacionales. En 1982 el mercado paralelo se establece para evitar esta pérdida de divisas.

El precio del dólar en el mercado paralelo aumentó gradualmente, pero siempre se mantuvo sobrevaluado y la brecha importaciones y exportaciones continuó.

El mercado paralelo falló en su objetivo de lograr la estabilidad en el mercado de divisas, y no logró mucho respecto a la mejor reasignación de estas. Pero permitió a las autoridades cierta devaluación gradual del colón que puede decirse evitó una alza súbita aún mayor en el momento en que se anuncia la devaluación oficial del colón y la nueva unificación cambiaria.

Sin embargo, la sobrevaluación del colón en estos anos tuvo un efecto importante sobre las exportaciones. A medida que el tipo de cambio en el mercado negro subia, los exportadores se vieron cada vez más desincentivados al tener que vender sus ingresos al tipo de cambio oficial más bajo.

Aunque la sobrevaluación no fue la única causa de la reducción de exportaciones si fue un factor importante como se ve reflejado en la medición econométrica presentada en este trabajo. Sin embargo, hay que considerar que más que la sobrevaluación en si, lo más probable es que sea la pérdida de confianza en el gobierno generada por las medidas adoptadas en este periodo lo que haya golpeado más fuertemente al sector exportador grupo que antes percibia no sólo fuertes ganancias de exportación, sino también contaba con el apoyo indiscutible del gobiemo.

Es pues factible que aunque la sobrevaluación haya significado una disminución considerable en las ganancias de exportación, haya sido un factor primordial la incertidumbre política que representaba el gobiemo democristiano para la clase exportadora.

En cuanto a las importaciones, el mercado paralelo no tuvo efectos significativos en la disminución de importaciones lo cual era de esperarse por las bajas elasticidades-precios de las importaciones en EI Salvador. En efecto, la sobrevaluación más bien favoreció la demanda de importaciones que sólo se vio frenada por las limitaciones de divisas.

Hubo una tendencia en la gente a reducir sus saldos reales para 
evitar la pérdida del poder adquisitivo del dinero. Esta pérdida se esperaba por las expectativas de inflación y por la inseguridad respecto al futuro político de la nación. Consecuentemente, cualquier expansión de la oferta monetaria iba acompanada de un aumento en la demanda de importaciones o en el consumo de bienes nacionales.

El comportamiento del nivel de precios muestra que las expectativas de inflación de la gente son un elemento importante en el proceso inflacionario. Estas expectativas de inflación están ligadas al comportamiento pasado de la inflación y a las expansiones monetarias.

El alza en precios se vio financiada por la expansión monetaria a que dio lugar principalmente el financiamiento de déficit fiscal. Cuando la devaluación oficial tiene efecto en enero de 1986, se produce un súbito y fuerte aumento en el nivel de precios no obstante que gran parte de esta devaluación habia sido ya incorporada al precio de los articulos.

Los superávits en la balanza de pagos en 1983 y 1984 se obtuvieron a través de endeudamiento externo.

La venta de divisas para importación se vieron subsidiadas a través de la deuda externa o de la disminución de reservas internacionales.

Por último, es importante sehalar de nuevo que elementos políticos y las reformas estructurales detrás de ellos y el conlfito bélico que generaron la pérdida de confianza del sector inversionista han sido factores decisivos en la recepción económica del pais.

Sin embargo, no hay que olvidar las causas estructurales que han generado esta lucha interna por el poder, y que constituyen el problema de fondo en el crecimiento económico del país. No puede esperarse que sin resolver estos problemas, ya no referentes a un determinado gobierno sino a las estructuras mismas de la economia, pueda lograrse la reactivación económica. 